\title{
Prevalence and incidence of cancer related lymphedema in low and middle-income countries: a systematic review and meta- analysis
}

Eric Torgbenu ${ }^{1,2^{*}}$, Tim Luckett ${ }^{1}$, Mark A. Buhagiar ${ }^{1,3}$, Sungwon Chang ${ }^{1}$ and Jane L. Phillips ${ }^{1}$

\begin{abstract}
Background: Little is known about the prevalence and incidence in low and middle-income countries (LMICs) of secondary lymphedema due to cancer. The purpose of the study is to estimate the prevalence and incidence in LMICs of secondary lymphedema related to cancer and/or its treatment(s) and identify risk factors.

Method: A systematic review and meta-analysis was conducted. Medline, EMBASE and CINAHL were searched in June 2019 for peer-reviewed articles that assessed prevalence and/or incidence of cancer-related lymphedema in LMICs. Risk of bias was assessed using the Joanna Briggs Institute Critical Appraisal Checklist for Prevalence Studies. Estimates of pooled prevalence and incidence estimates were calculated with 95\% confidence intervals (CI), with sub-group analyses grouping studies according to: country of origin, study design, risk of bias, setting, treatment, and lymphedema site and measurement. Heterogeneity was measured using $X^{2}$ and $I^{2}$, with interpretation guided by the Cochrane Handbook for Systematic Reviews.

Results: Of 8766 articles, 36 were included. Most reported on arm lymphedema secondary to breast cancer treatment $(n=31)$, with the remainder reporting on leg lymphedema following gynecological cancer treatment $(n=5)$. Arm lymphedema was mostly measured by arm circumference ( $n=16 / 31$ studies), and leg lymphedema through self-report ( $n=3 / 5$ studies). Eight studies used more than one lymphedema measurement. Only two studies that measured prevalence of leg lymphedema could be included in a meta-analysis (pooled prevalence $=$ $10.0,95 \% \mathrm{Cl} 7.0-13.0, P^{2}=0 \%$ ). The pooled prevalence of arm lymphedema was $27 \%$, with considerable heterogeneity (95\% Cl 20.0-34.0, $P^{2}=94.69 \%, n=13$ studies). The pooled incidence for arm lymphedema was $21 \%$, also with considerable heterogeneity (95\% CI 15.0-26.0, $P^{2}=95.29 \%, n=11$ studies). There was evidence that higher body mass index ( $>25$ ) was associated with increased risk of arm lymphedema (OR: 1.98, 95\% Cl 1.45-2.70, $P^{2}=$ $84.0 \%, P<0.0001, n=4$ studies).

(Continued on next page)
\end{abstract}

\footnotetext{
* Correspondence: eric.l.torgbenu@student.uts.edu.au

${ }^{1}$ Improving Palliative, Aged and Chronic Care through Clinical Research and

Translation (IMPACCT), Faculty of Health, University of Technology Sydney, Sydney, New South Wales, Australia

2Department of Physiotherapy and Rehabilitation Sciences, University of Health and Allied Sciences, Ho, Ghana

Full list of author information is available at the end of the article
}

(c) The Author(s). 2020 Open Access This article is licensed under a Creative Commons Attribution 4.0 International License, which permits use, sharing, adaptation, distribution and reproduction in any medium or format, as long as you give appropriate credit to the original author(s) and the source, provide a link to the Creative Commons licence, and indicate if changes were made. The images or other third party material in this article are included in the article's Creative Commons licence, unless indicated otherwise in a credit line to the material. If material is not included in the article's Creative Commons licence and your intended use is not permitted by statutory regulation or exceeds the permitted use, you will need to obtain permission directly from the copyright holder. To view a copy of this licence, visit http://creativecommons.org/licenses/by/4.0/ The Creative Commons Public Domain Dedication waiver (http://creativecommons.org/publicdomain/zero/1.0/) applies to the data made available in this article, unless otherwise stated in a credit line to the data. 
(Continued from previous page)

Conclusion: Better understanding the factors that contribute to variability in cancer-related arm lymphedema in

LMICs is an important first step to developing targeted interventions to improve quality of life. Standardising

measurement of lymphedema globally and better reporting would enable comparison within the context of

information about cancer treatments and lymphedema care.

Keywords: Lymphedema, Prevalence, Incidence, Risk factor, Cancer related lymphedema, LMICs

\section{Background}

Lymphedema is a distressing and often persistent condition that occurs when fluid accumulates in the extracellular tissue spaces causing swelling, predominately in the extremities [1]. Lymphedema is classified as congenital, primary or secondary. Secondary lymphedema occurs as a sequelae to another condition, such as the surgical and/or radiation treatments of cancer [2, 3].

Lymphedema is characterised by heaviness and discomfort, decreased range of motion, recurrent skin infections, elephantiasis verruca nostra, recurrent skin ulcers, cutaneous angiosarcoma, as well as psychological effects including depression, anxiety, and negative body image [4]. These effects impact adversely on quality of life [5].

Systematic reviews of the estimates incidence and prevalence of cancer-related lymphedema have focused almost exclusively on high-income countries (HICs). A 2013 systematic review and meta-analysis found the incidence of unilateral arm lymphedema post breast cancer treatment ranged from 8.4 to $21.4 \%$ [6]. Another systematic review estimated the prevalence of secondary lymphedema due to non-specific cancer in United Kingdom (UK) lymphedema specialist clinics $(n=11,555)$ to be 2.05-3.99:1000 [7]. Risk factors for lymphedema identified in the literature have included obesity at the time of a cancer diagnosis, receipt of chemotherapy, adjuvant radiation therapy, type of surgery, physiotherapeutic modalities, and number of lymph nodes removed $[6,8]$.

No review to date has reported on the pooled prevalence or incidence of lymphedema in LMICs and associated risk factors, making it difficult to advocate for and plan appropriate services to manage this condition.

\section{Aim}

To estimate the prevalence and incidence in LMICs of secondary lymphedema related to cancer and/or its treatment(s) and identify risk factors.

\section{Methods}

A systematic review and meta-analysis was registered with the International Prospective Register of Systematic Reviews (PROSPERO) [CRD42019137641] [9]. This review is reported in accordance with the preferred reporting items for systematic reviews and meta-analyses (PRISMA) guidelines [10]. This paper reports on the cancer-related lymphedema component of a larger review across lymphedema from all causes.

\section{Eligibility criteria}

Primary studies in peer-reviewed journals of any design that estimated prevalence or incidence of secondary lymphedema in a sample from a LMIC, as defined by The World Bank Group [11] criteria. Where studies evaluated an intervention, only the baseline data were included. Studies using various measures of secondary lymphedema, including self-report and objective measures were included. Where studies were published in languages other than English, native language speakers were contacted to do the extraction according to the predefined criteria. Editorials, comment papers, review papers, case reports, and case series were excluded.

\section{Information sources}

Database searches were conducted of Medline, Excerpta medica database (EMBASE) and Cumulative Index of Nursing and Allied Health Literature (CINAHL). A hand search of the reference lists of included studies was also performed.

\section{Search strategy}

Databases were searched on seventh of June 2019 without any limit on date or language. Subject headings and keywords related to lymphedema and LMICs. The initial search strategy was developed in Medline and adapted for other bibliographic databases (refer to Table 1).

\section{Study selection}

The first author (E.T.) assessed titles and abstracts of all citations retrieved by the search for relevance against the inclusion criteria, obtaining full texts as required to make a decision. $10 \%$ of articles were independently screened by a second author (T.L., M.B. or J.P.), with screening continued by E.T. alone after finding $100 \%$ agreement.

\section{Data extraction}

Data were extracted by the first author (E.T.), with random checks performed by a second (T.L.). Data items 
Table 1 Search strings for systematic review and meta-analysis

Medline

No. Searches

1. $\quad((()((($ Afghanistan* or Benin* or Burkina Faso* or Burundi* or Central African

Republic ${ }^{*}$ or Chad* or Comoros* or Congo* or Eritrea* or Ethiopia* or Gambia*

or Guinea-Bissau* or Haiti* or Korea Republic* or Liberia* or

Madagascar* or

Malawi* or Mali* or Mozambique* or Nepal* or Niger* or Rwanda* or Sierra

Leone* or Somalia* or South Sudan* or Syrian Arab Republic* or

Tajikistan* or

Tanzania* or Togo* or Uganda* or Yemen* or Zimbabwe* or Angola* or

Bangladesh* or Bhutan* or Bolivia* or Cabo Verde* or Cambodia* or Cameroon*

or Congo* or Ivory Coast* or Djibouti* or Egypt* or El Salvador* or Georgia* or

Ghana* or Honduras* or India* or Indonesia* or Kenya* or Kiribati* or Kosovo* or

Kyrgyz Republic* or Lao PDP* or Lesotho* or Mauritania* or

Micronesia* or

Moldova* or Mongolia* or Morocco* or Myanmar* or Nicaragua*

or Nigeria* or

Pakistan* or Papua New Guinea* or Philippines* or Sao Tome) and

Principe*) or

Solomon Islands* or Sri Lanka* or Sudan* or Swaziland* or TimorLeste* or

Tunisia* or Ukraine* or Uzbekistan* or Vanuatu* or Vietnam* or West Bank) and

Gaza*) or Zambia* or Albania* or Algeria* or American Samoa* or Armenia* or

Azerbaijan* or Belarus* or Belize* or Bosnia) and Herzegovina*) or Botswana* or

Brazil* or Bulgaria* or China* or Colombia* or Costa Rica* or Cuba*

Dominica* or Dominican Republic* or Equatorial Guinea* or Ecuador* or Fiji* or

Gabon* or Grenada* or Guatemala* or Guyana* or Iran* or Iraq* or Jamaica* or

Jordan* or Kazakhstan* or Lebanon* or Libya* or Macedonia* or

Malaysia* or

Maldives* or Marshall Islands* or Mauritius* or Mexico* or

Montenegro* or

Namibia* or Nauru* or Paraguay* or Peru* or Romania* or Russian Federation*

or Samoa* or Serbia* or South Africa* or Saint Lucia* or Saint

Vincent) and the

Grenadines*) or Suriname* or Thailand* or Tonga* or Turkey* or

Turkmenistan*

or Tuvalu* or Venezuela*).mp.

2. ((Developing or underdeveloped or under-developed or lessdeveloped or least-developed) adj world).mp.

3. (Asia* or Africa* or Caribbean* or central America* or south America* or Melanesia* or Micronesia* or Polynesia*).mp.

4. ((developing or underdeveloped or under-developed or lessdeveloped or least developed

or less-economically developed or less-affluent or least-affluent) adj (country or countries or nation or nations or region or regions or economy or economies)).mp.

5. (Third-world* or third world* or 3rd-world*).mp.

6. Developing countries/ or exp. africa/ or exp. Caribbean region/ or exp. central

America/ or latin America/ or exp. south america/ or asia/ or exp.
Table 1 Search strings for systematic review and meta-analysis (Continued)

\section{Medline}

No. Searches

asia, central/ or

exp. asia, southeastern/ or exp. asia, western/ or exp. indian ocean islands/ or

pacific islands/ or exp. melanesia/ or exp. micronesia/ or exp. west indies/

7. $\mathrm{or} / 1-6$

8. edema.mp. or Edema/

9. oedema.mp.

10 Elephantiasis, Filarial/ or lymphoedema.mp. or Elephantiasis/

11. exp Lymphedema/

12. Iymhoedema.mp.

13. Breast Cancer Lymphedema/ or lymphedema.mp. or Non-Filarial Lymphedema/

14. *lymphedema/

15. *edema/

16. $\exp$ Edema/

17. 8 or 9 or 10 or 11 or 12 or 13 or 14 or 15 or 16

18. 7 and 17

19 limit 18 to humans

20. $\quad((((()((' A n d o r r a '$ or 'Antigua) and Barbuda') or 'Argentina' or 'Aruba' or 'Australia' or

'Austria' or 'Bahamas' or 'Bahrain' or 'Barbados' or 'Belgium' or 'Bermuda' or

'British virgin islands' or 'Brunei Darussalam' or 'Canada' or 'Cayman Islands' or

'Channel Islands' or 'Chile' or 'Croatia' or 'Curacao' or 'Cyprus' or 'Czech Republic' or

'Denmark' or 'Estonia' or 'Faroe Islands' or 'Finland' or 'France' or 'French Polynesia'

or 'Germany' or 'Gibraltar' or 'Greece' or 'Greenland' or 'Guam' or

'Hong Kong Sar' or

'China' or 'Hungary' or 'Iceland' or 'Ireland' or 'Isle of Man' or 'Israel' or 'Italy' or

'Japan' or 'Korea' or 'Kuwait' or 'Latvia' or 'Liechtenstein' or

'Lithuania' or

'Luxembourg' or 'Macao Sar' or 'Malta' or 'Monaco' or 'Netherlands' or 'New

Caledonia' or 'New Zealand' or 'Northern Mariana Islands' or

'Norway' or 'Oman' or

'Palau' or 'Panama' or 'Poland' or 'Portugal' or 'Puerto Rico' or 'Qatar' or 'San

Marino' or 'Saudi Arabia' or 'Seychelles' or 'Singapore' or 'Sint Maarten' or 'Slovak

Republic' or 'Slovenia' or 'Spain' or 'Saint Kitts) and Nevis') or 'Saint Martin' or

'Sweden' or 'Switzerland' or 'Taiwan' or 'Trinidad) and Tobago') or

Turks) and Caicos

Islands') or 'United Arab Emirates' or 'United Kingdom' or 'United

States' or

'Uruguay' or 'Virgin Islands').mp.

21. 19 not 20

extracted included: year and country, setting, aims, study design, sample size, sampling method, lymphedema site, stage, severity and duration, the type of management 
reported, and estimates of lymphedema prevalence or incidence.

\section{Risk of bias (quality) assessment}

The first author (E.T.) independently assessed risk of bias for each study using the Joanna Briggs Institute Critical Appraisal Checklist for Prevalence Studies [12]. $20 \%$ of articles were independently assessed by the second author (T.L.), with the remaining risk of bias assessment continued by E.T. alone after a 100\% agreement. Disagreements were resolved by discussion or, and when necessary, a third person arbitrating. The tool consists of 9 items which assess the internal and external validity of studies included in the quantitative analysis [12]. Studies were classified into low or high risk of bias using a cutoff of $70 \%$.

\section{Statistical analysis}

Meta-analyses of incidence and prevalence data were undertaken separately in accordance with the Cochrane Handbook for Systematic Reviews, using a random effects models [13]. The summary measure was the prevalent or incident percentage of people with lymphedema, with 95\% confidence intervals. Following Ressing et al. [14], we assumed that cohort studies yielded estimates of incidence whereas cross-sectional studies yielded estimates of prevalence. Heterogeneity between estimates was measured using $X^{2}$ and $\mathrm{I}^{2}$ statistics, using recommended thresholds [15]. For studies that used multiple lymphedema measurements, we prioritized the following measures based on level of objectivity [16, 17]: 1) circumferential measurement [18]; 2) perimetry (assessing difference in limb sizes, similar to the circumferential measurement) [6]; 3) limb volume measurement; 4) bioimpedence spectroscopy; or 5) self-report.

\section{Analysis of subgroups or subsets}

Subgroup analyses were conducted on an a priori basis for studies classified according to whether or not estimation of prevalence/incidence was a stated aim of the study, and low risk of bias. Further subgroup analyses were conducted post hoc to explore any significant heterogeneity based on study characteristics such as country, setting, sample size, site and measurement of lymphedema and study design. Where studies were not considered sufficiently similar to be included in a meta-analysis, synthesis used a narrative approach based on the methods published by the Lancaster University, UK [19].

\section{Results}

Of the 8766 articles that were retrieved, 1231 articles were excluded due to duplication. The remaining 7535 articles were evaluated, and 7109 were excluded based on their title and abstract. Next, 426 full-text articles were assessed and 389 were excluded, leaving 36 articles for inclusion reporting 36 studies (Refer to Fig. 1).

\section{Characteristics of included studies}

The majority of studies $(n=34)$ focused on women $(n=$ $12,145)$, while two studies [20, 21] involved both men and women. All studies were conducted between 2001 and 2019 and three studies [22-24] were reported in non-English language publications (Refer to Table 2).

While the majority of studies were conducted in Brazil $(n=12)$ and Turkey $(n=9)$, most other regions with LMIC were represented, including: South America $(n=$ 12) $[5,20,24,32-39,49]$, Europe $(n=11)[21,23,25-31$, $50,51]$, Southern Asia $(n=6)[41-45,52]$, West Africa $(n=3)$ [22, 40, 53], Middle East $(n=3)[47,48,54]$ and East Asia and Pacific $(n=1)$ [46].

Most studies were cross-sectional $(n=21)$, with a smaller number of prospective cohort $(n=8)$, retrospective cohort $(n=3)$ and case-control studies $(n=4)$. The majority of studies $(n=34)$ reported exclusively on either arm $(n=30)$ or leg $(n=4)$ lymphedema, while two [20, 40] reported on both. One study reported on lymphedema of the chest and arm secondary to breast cancer treatment [35]. This study was the only study to use bioelectric impedance to diagnose lymphedema [35]. Other methods used for measuring and defining lymphedema included: tape measurement $(n=16)[21,25,27-30,32$, $37,38,41-43,45,47,48,54]$; patient self-report $(n=8)$ $[22,33,39,44,46,50,52,53]$; water volumeter $(n=2)$ [31, 36]; palpation and clinical diagnosis $(n=2)[40,49]$; and perometer $(n=1)$ [34].

Twenty-five studies reported lymphedema prevalence and 11 studies reported incidence.

Of the three studies that explored the risk of developing lymphedema associated with cancer staging both in the leg and arm, two involved women with breast cancer [30, 41] and the other, women with vulvar cancer [49]. Four studies reported on the risk of developing arm lymphedema associated with breast cancer treatment among women who had sentinel lymph node biopsy [5, 21, 29, 37]. Variations in the timing or the onset of cancer related lymphedema ranged from 3 months to over 5 years post diagnosis and treatment. The type of management received by women with cancer related lymphedema included: lymphatic drainage [29], physiotherapeutic modalities such as care for the affected limb, home exercises and self-lymphatic drainage [24, 28, 39], hormonal therapy [54] and neo-adjuvant therapy including radiotherapy and chemotherapy [34, 38].

\section{Synthesis}

Arm lymphedema following breast cancer treatment The majority of studies $(n=31)$ reported arm lymphedema secondary to breast cancer treatment. However, 


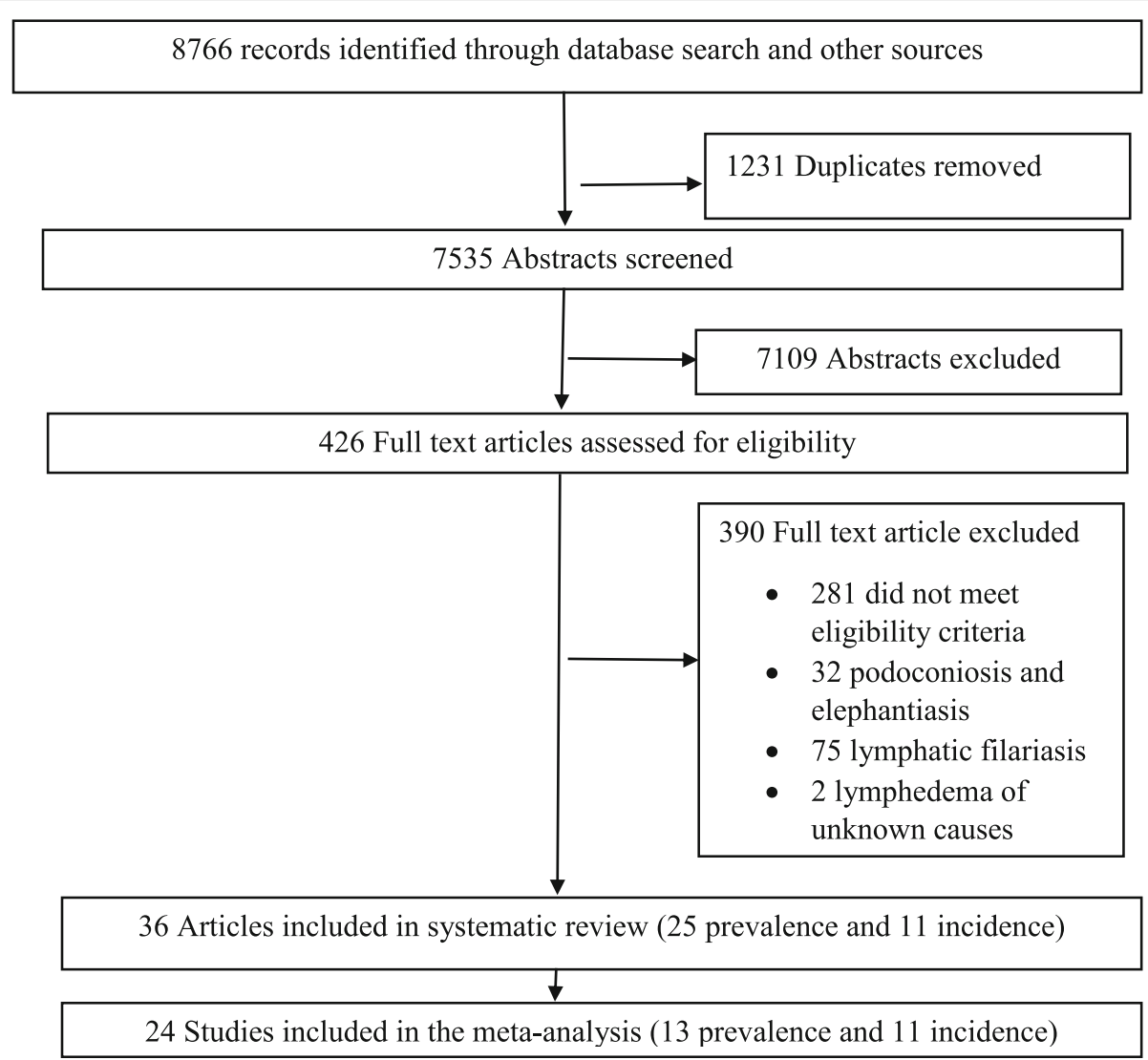

Fig. 1 Flow diagram of study selection for inclusion in this review and meta-analysis

lymphedema was defined differently based on the method of measurement used. Half of these studies $(n=$ 16) used circumferential measurements [21, 25, 27-30, $32,37,38,41-43,45,47,48,54]$. The remainder either used self-reports of swelling in the arms $(n=5)[33,39$, $44,46,52]$, volumetric measurement $(n=2)$ [31, 36], perimetry $(n=1)[34]$ and/or bioimpedance spectrometry $(n=1)$ [26]. Six studies used more than one method of arm lymphedema diagnosis [5, 20, 23, 24, 36, 51].

Eleven studies $(n=11)$ compared circumferential measurement in bilateral limbs using a range difference of $\geq 2 \mathrm{~cm}$ as indicative of lymphedema. One study from Brazil only used a difference of $\geq 1 \mathrm{~cm}$ circumferential measurement in the presence of any other two lymphedema symptoms of heaviness, swelling, tightness or firmness in the affected limb [5]. Another study [23] which examined the upper extremity disorders among breast cancer women undergoing surgery measured lymphedema as circumferential measurement difference $\geq 1.5 \mathrm{~cm}$ in the affected limb. There was only one large population study involving Turkish women with breast cancer $(n=5064)$, which used a cut-off difference of $\geq 5 \mathrm{~cm}$ in the affected limb as a diagnosis for lymphedema [28]. All Turkish studies $(n=7)$ measured arm lymphedema by the circumferential method, while the Brazilian $(n=3)[24,33,39]$ and Indian $(n=2)[44,52]$ studies used patients' self-reports.

Studies which used the volumetric measurement defined lymphedema to be a cut-off difference in volume based on circumferential measurements of both limbs > $10 \%$ percent $[31,36]$. Lymphedema was diagnosed as an impedance ratio of greater than 10 in the affected limb using the bioimpedance spectrometer [26].

Prevalence of arm lymphedema following breast cancer treatment The most common method of arm lymphedema measurement was arm circumference $(n=$ 16), while several studies $(n=9)$ also used more than just one lymphedema measurement. One study used lymphoscintigraphy as a technique in the measurement of lymphedema among Brazilian post-breast cancer women [37]. All studies included in this review reported prevalence of arm lymphedema secondary to breast cancer treatment. Twenty-five studies reported prevalence estimates $[5,22,23,25,27,31-40,43,45-51,53,54]$. The prevalence estimate among post breast cancer treated women varied from $0.4 \%$ in Papua New Guinea [46] to 92.5\% reported by a Brazilian study [31]. The lowest 


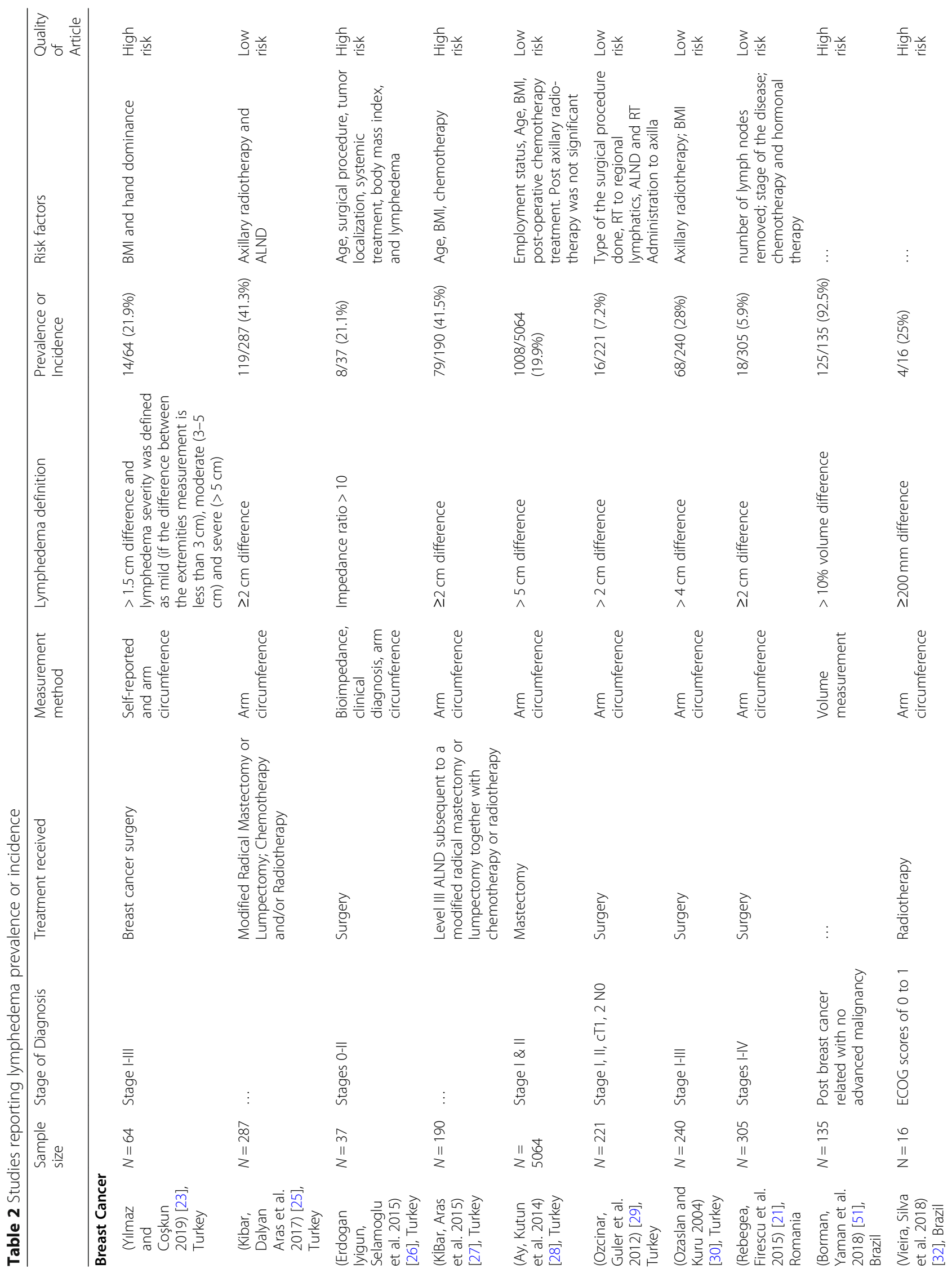




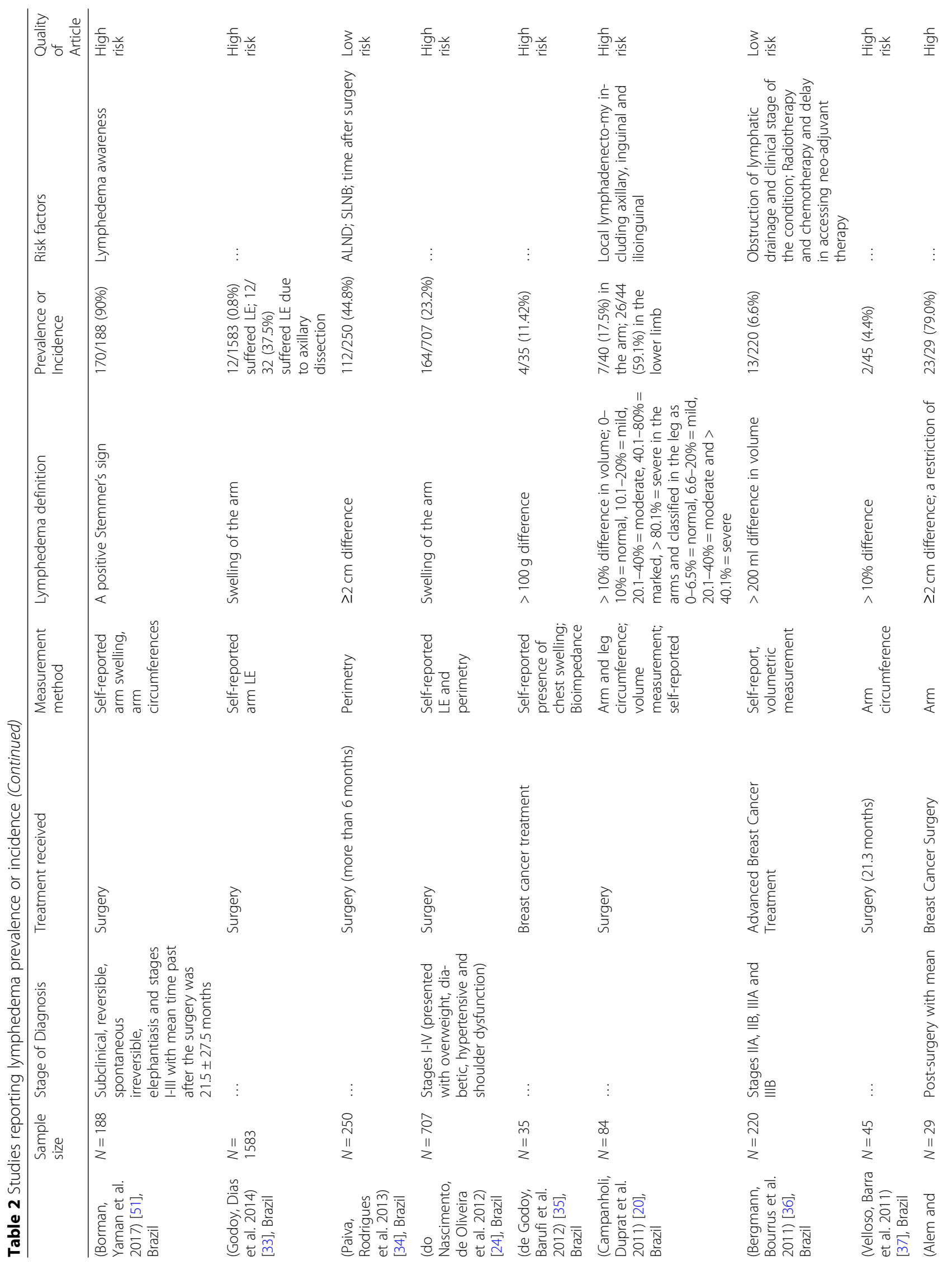




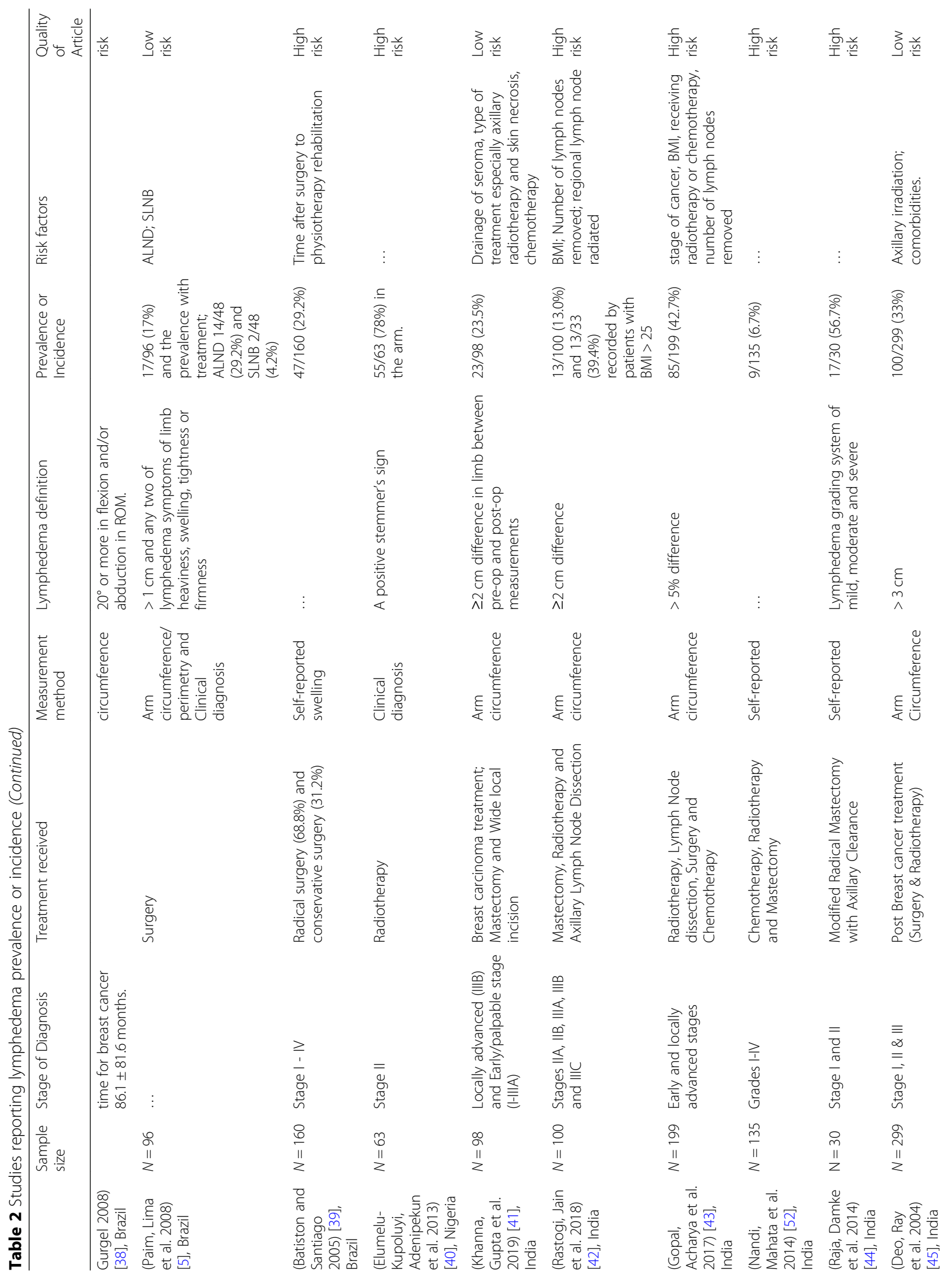




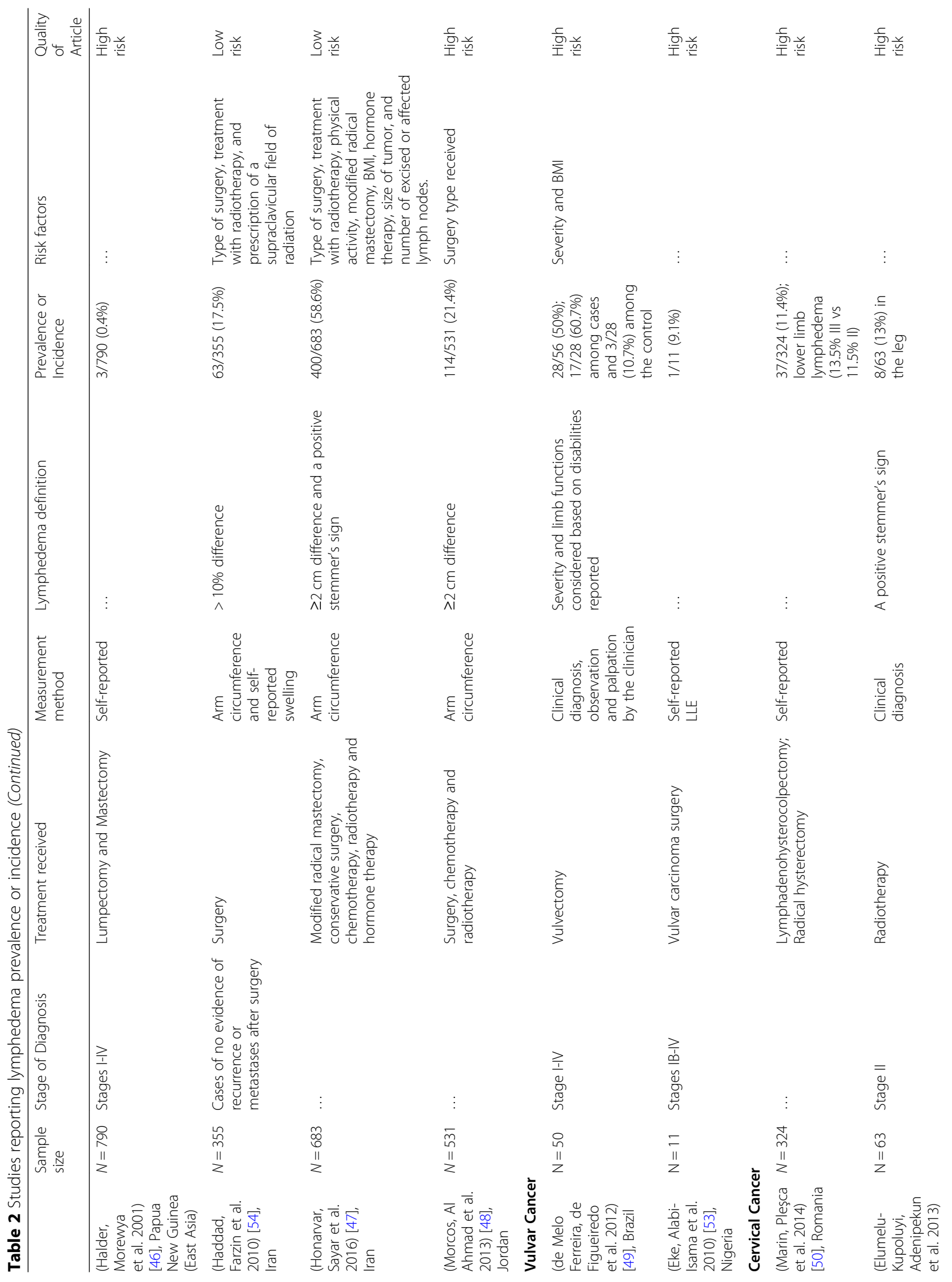




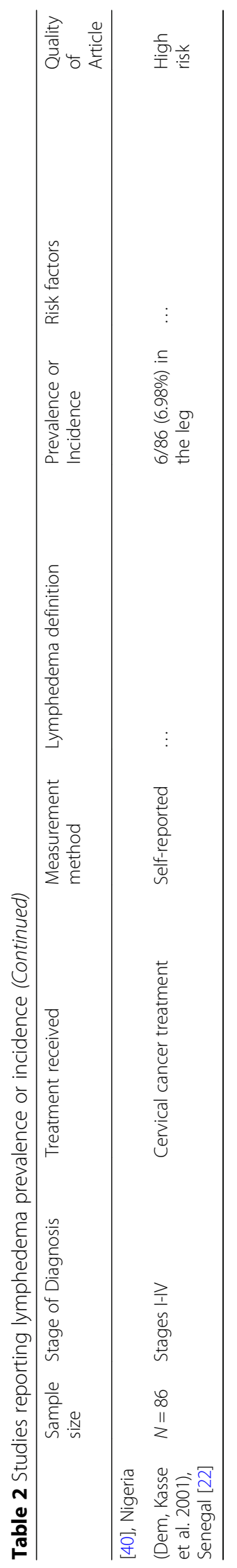


estimate of $0.4 \%$ was reported by self-report of lymphedema [46]. Of the two studies that reported on sentinel lymph node biopsy, the prevalence estimates were relatively low compared with other studies; $4.4 \%$ (95\% CI 1.0-15.0) [37] and 17.0\% (95\% CI 11.0-27.0) [5].

Using data abstracted from 13 studies the pooled estimate for prevalence of breast cancer related lymphedema was 30\% (95\% CI 24-37). There was considerable heterogeneity among studies $\left(\mathrm{I}^{2}=91.66 \%, p=0.001\right)$ (refer to Fig. 2). Heterogeneity was not reduced in a subgroup analysis of studies grouped by a single country, Brazil (pooled prevalence $=31,95 \%$ CI 19.0-43.0, $I^{2}=$ $87.21 \%, n=5$ studies). Studies from the Middle East (i.e. Iran [54], Jordan [48] and Turkey [23]) demonstrated considerable heterogeneity $\left(\mathrm{I}^{2}=94.69 \%, p=0.001\right)$, which increased to considerable heterogeneity when a second Turkish study [25] was included $\left(\mathrm{I}^{2}=99.67 \%\right.$, $p=0.001)$. The pooled prevalence recorded by the two Turkish studies was 37\% (95\% CI 32-42) among breast cancer women receiving treatment in cancer units (refer to Fig. 3).

Incidence of arm lymphedema following breast cancer treatment Eleven [11] studies reported incidence of unilateral arm lymphedema [20, 21, 24, 26, 28-30, 41, $42,44,52]$, while one study reported lymphedema of both arm and leg [20]. The follow up periods varied among studies from 6 months to over 5 years post- cancer treatment.

The lowest incidence was $5.9 \%$ after breast cancer treatment in Romania [21] with a mean follow up period of 24 months, who received sentinel lymph node biopsy. The highest incidence was $56.7 \%$ recorded in an Indian study with 6-month follow up after modified radical mastectomy treatment for breast cancer patients [44]. Breast cancer related lymphedema incidence in Turkey ranged from $7.2 \%$ recorded within a population sample with a median follow up of 64 months [29] to $28 \%$ in a population sample with a median follow up of 30 months after breast cancer treatment [30]. The incidence of arm lymphedema reported by the Brazilian studies ranged from 17.5 to $23.2 \%$ [20, 24]. The pooled incidence was $21 \%\left(95 \%\right.$ CI $15.0-26.0, I^{2}=95.29 \%$, $n=11$ studies) with considerable heterogeneity, while that reported by circumferential measurement was $16 \%$ (95\% CI 9.0-23.0, $I^{2}=96.54 \%, n=6$ studies) (refer to Fig. 4). The estimated pooled incidence by all other methods of assessment was between 16.0\% (circumferential measurement) and $26.0 \%$ (self-report).

Risk factors of lymphedema following breast cancer treatment Ten of the 11 studies reporting on lymphedema risk factors, focused on the risk of developing arm lymphedema following breast cancer treatment [21,

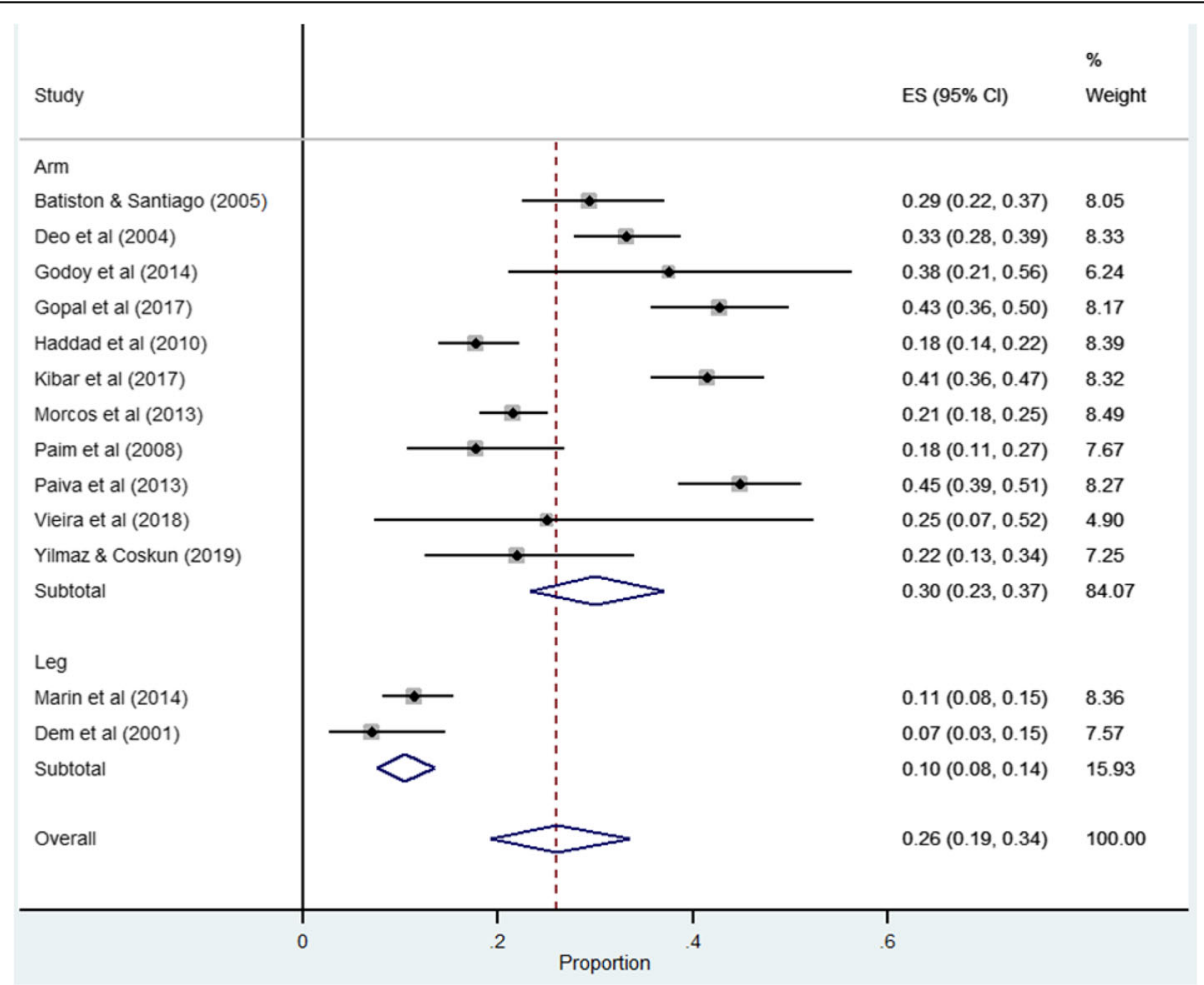

Fig. 2 Forest plot of pooled prevalence of arm and leg lymphedema 


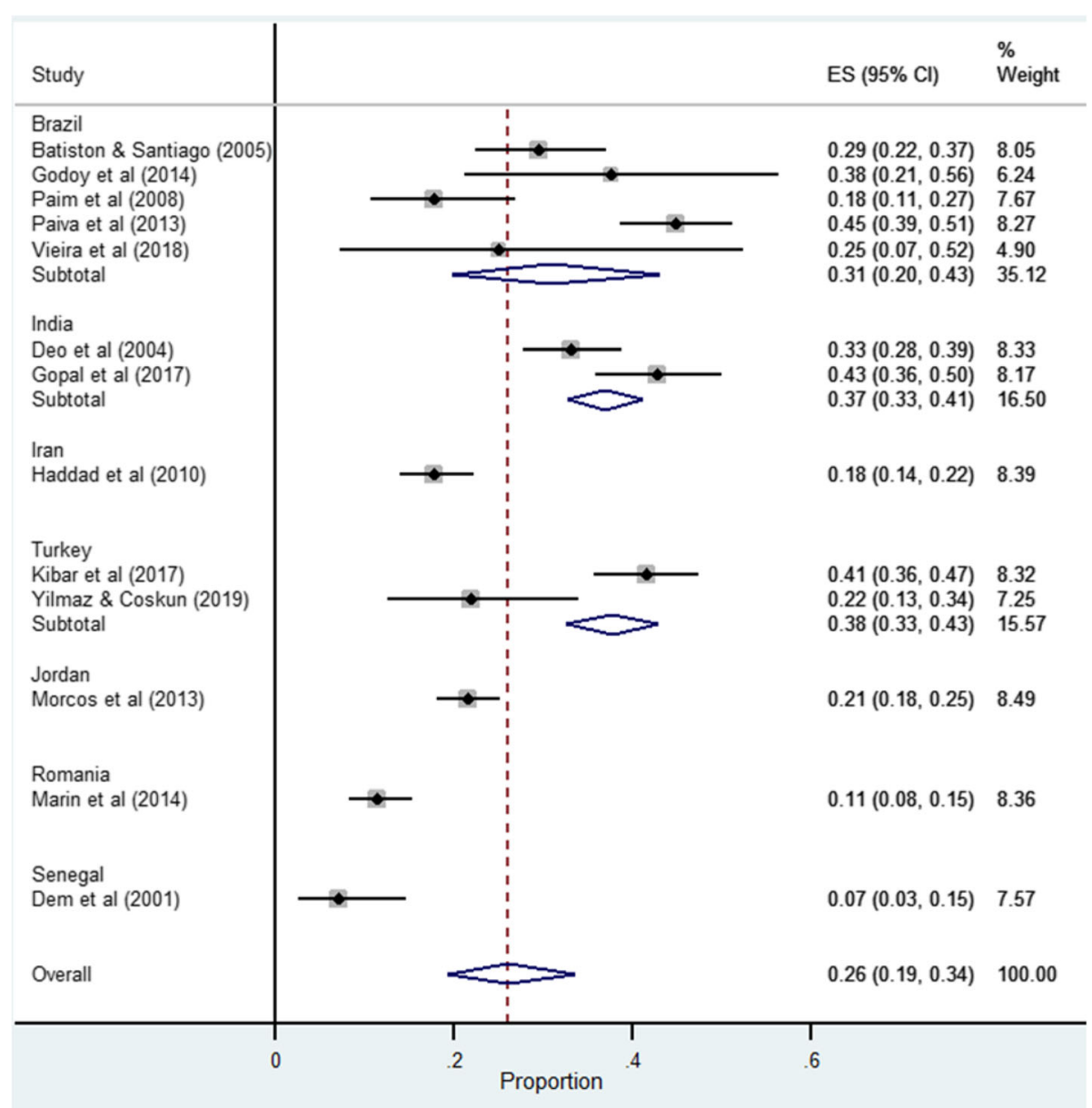

Fig. 3 Forest plot of pooled prevalence of cancer related lymphedema based on country of study publication

$27-30,34,41,42,45,47]$. One study [28] reported that individuals with body mass index (BMI) of $\geq 30$ were 6.64 times more likely to develop arm lymphedema than those with BMI $\leq 17.9$. The risk of developing arm lymphedema among breast cancer women with $\mathrm{BMI} \geq 25$ ranges from the odds ratio (OR) of 1.5 to 5.9 compared to participants with $\mathrm{BMI}<25[27,28,30,42,47]$. We obtained a pooled effect estimate OR of $1.98,95 \%$ confidence interval $(\mathrm{CI}): 1.45$ to $2.70\left(P<0.0001 ; I^{2}=84.0 \%\right)$ in a random effect meta-analysis (refer to Fig. 5).

Axillary radiotherapy treatment is a significant risk with an OR ranging from 2.7 to 4.4 [21, 27, 29]. Four studies examined the risk of developing arm lymphedema associated with higher number of lymph node removal among breast cancer survivors [21, 27, 42, 47]. The removal of lymph nodes of $>25$ during mastectomy was associated with a risk of developing arm lymphedema [4.88 (OR2.25-10.58)] among breast cancer woman compared with when less number of lymph nodes were removed [21]. Higher nodal ratio [1.135 (Hazard ratio (HR) 1.037-1.243)] was also found to be associated with higher risk of arm lymphedema [42]. Lumpectomy was not a significant risk factor for arm lymphedema [27].

Modified radical mastectomy was associated with an OR of 4.3 (95\% CIs: 2.3-7.9) risk than those who did not and participants who received radiotherapy had an OR of 3.9 (95\% CIs: 1.8-8.2) risk of developing arm lymphedema compared with those who did not [47]. The length of time after surgery for breast cancer was also reported to be 9.7 times higher among breast cancer women who had surgery more than 5 years as compared to those with less years [34].

Other risk factors identified to significantly affect lymphedema among breast cancer survivors include: past history of limb damage had an OR of 1.7 (95\% CIs: 0.93.1) [47], presence of a co-morbid condition with a HR of 0.1593 (95\% CIs: 1.1441-2.9369) [45], post radiotherapy moist desquamation had an OR of 4.34 (95\% CIs: 1.07-17.65) [41], and presence of seroma after breast cancer surgery [34]. Women with breast cancer tumour invasion were 13.7 times at risk of developing arm 


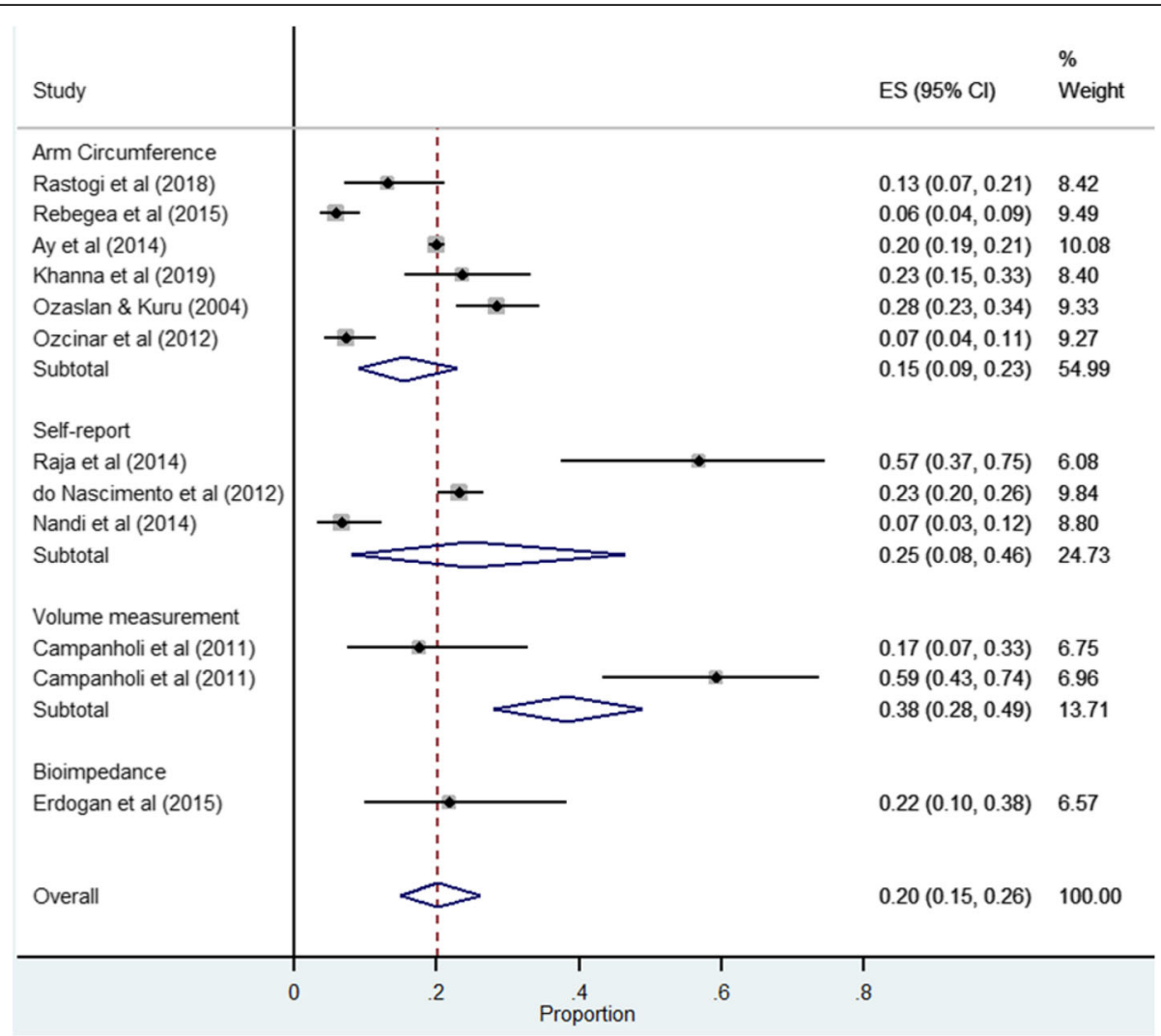

Fig. 4 Forest plot of pooled lymphedema incidence according to arm lymphedema measurement methods

lymphedema compared to those women who did not receive tumour invasion [47]. Cancer stage was not significant in arm lymphedema following breast cancer treatment $[34,41]$ (refer to Table 3).

\section{Leg lymphedema following gynecological cancer treatment} All five studies that reported leg lymphedema used either patient self-report $(n=3)$ or palpation or clinical diagnosis $(n=2)$. Studies which used the self-report method of lymphedema diagnosis only used either palpation or observation methods of identifying lymphedema in the affected limbs of the patients [22, 50, 53]. These were based on patients' reports of swelling in the legs alone. In the case of the clinical diagnosis, lymphedema was identified as present when a positive Stemmer's sign was recorded [40].

Prevalence of leg lymphedema following gynecological cancer treatment Of the five studies reporting on leg lymphedema, three focused on the prevalence of leg lymphedema secondary to cervical cancer treatment; two West African and one Romanian [22, 40, 50]. The prevalence estimates were similar; 7.0\% (95\% CI 3-15) [22], $11.0 \%$ (95\% CI 8-15) [50] and 13\% (95\% CI 7-23) [40]. The three studies $[22,40,50]$ that reported on leg lymphedema following cervical cancer reported a pooled prevalence of $10 \%$ (95\% CI 7-13) with considerable heterogeneity. The method of measurement of lymphedema was self-report and none of these studies explored leg lymphedema risk factors.

Two studies reported leg lymphedema prevalence based on clinical diagnosis among women who received vulvectomy $[49,53]$. The prevalence varied widely from $60.1 \%$ in the Brazilian study to $9.1 \%$ in the Nigerian study [53].

The incidence of leg lymphedema was reported in only one study, which focused on patients following inguinal and ilioinguinal lymphadenectomies in Brazil and identified an incidence of $59.1 \%$ [20].

Risk factors of lymphedema following vulvar cancer treatment One study reported the risk of developing leg lymphedema following vulvar cancer treatment [49]. The risk of leg lymphedema following vulvar cancer included age associated with an OR of 1.09 (95\% CIs: 1.00-1.18) and a BMI with an OR of 1.34 (1.01-1.77) [49] (refer to Table 3).

Sub-group analyses Planned sub-group analyses failed to significantly reduce heterogeneity. Heterogeneity 


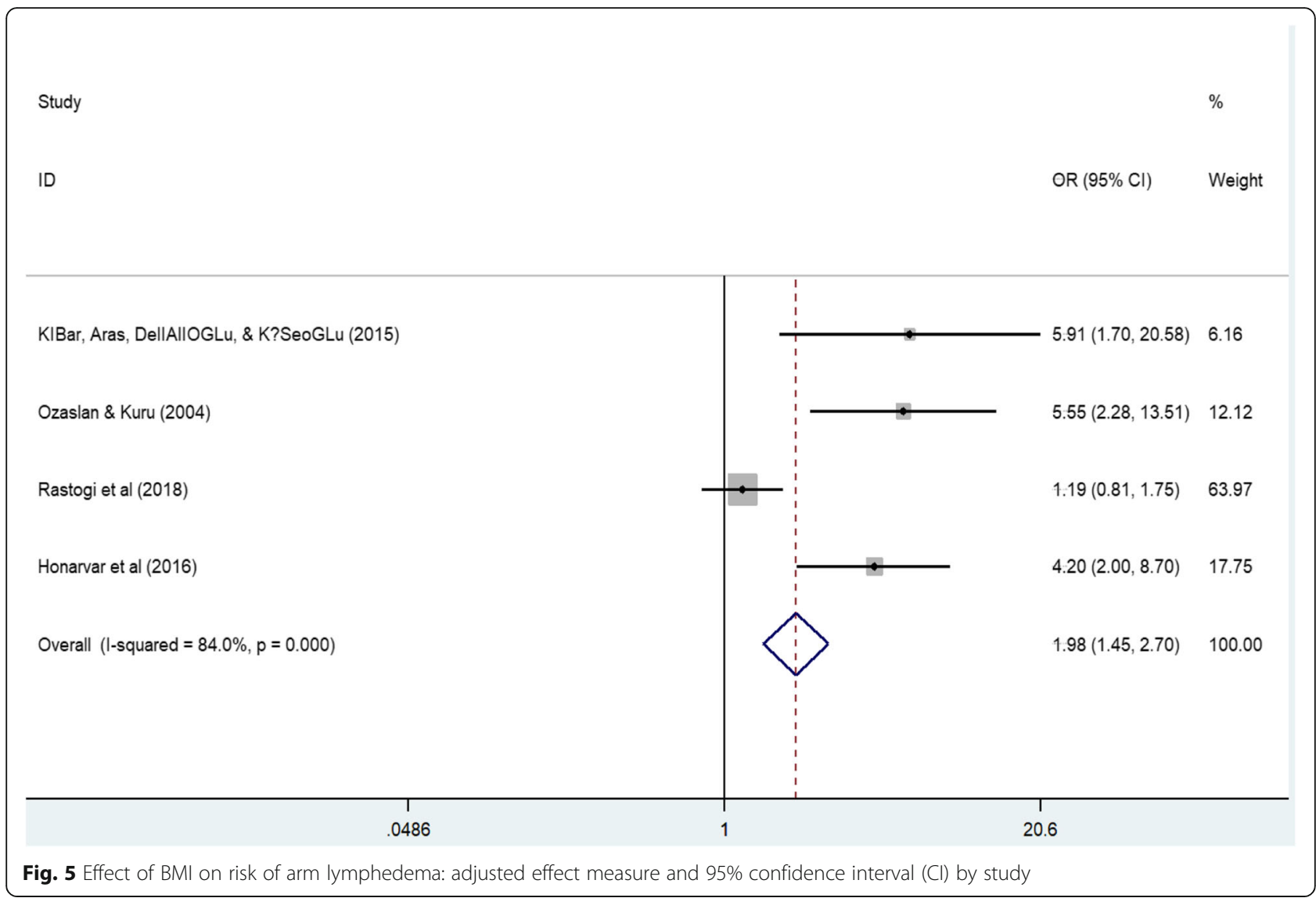

based on: country of study publication and the type of cancer was 95.29\%; study region was 93.85\%; sample size, the type of measurement of lymphedema, and the design of the study were $94.69 \%$. The level of heterogeneity was $97.2 \%$ ( $n=5$ studies) for incidence and $94.89 \%$ ( $n=6$ studies) for prevalence when focusing on low risk of bias studies (refer to Table 4).

A post-hoc subgroup analysis was also conducted in which we removed from the meta-analyses all studies that had less than 24 months follow up $(n=5)$. This too resulted in minimal improvement in heterogeneity.

\section{Discussion}

This systematic review and meta-analysis is the first to attempt to estimate prevalence and incidence of lymphedema in LMICs. Arm lymphedema results were too heterogeneous to reliably estimate prevalence or incidence. Two studies suggest that the prevalence of leg lymphedema may be between 7 and 13\% [22, 50], while only one study estimated incidence of leg lymphedema, estimating it to be $59.1 \%$, focusing specifically on Brazilian patients following ilioinguinal lymphadenectomy [20].

Differences in study quality, sample size estimations, technique of sampling and study methodology typically form the bases for heterogeneity in meta-analysis of prevalence or incidence data, and this review is likely to be no exception. Lymphedema following cancer treatment might be influenced by lymphatic drainage, adjuvant radiation therapy, hormonal therapy, skin care, physiotherapeutic modalities such as simple home exercises, and self-lymphatic drainage techniques [55] and trastuzumab therapy and taxane-based chemotherapy [56], but none of these variables were reliably reported. Risk factors for arm lymphedema following breast cancer treatment identified by this review did not differ from those identified by studies in HICs $[6,57,58]$. BMI $\geq 25$, age above 60 years, having axillary radiotherapy treatment with axillary lymph node dissection, $\geq 16$ lymph nodes removed, higher lymph node ratio, and increased engagement in moderate to severe physical activity were identified as the most significant risk factors of arm lymphedema. The number of lymph nodes typically removed in LMICs may be more compared to HICs because of later detection of cancer and differences in $t$ the type of treatment provided as standard. Such differences in treatments and health management practices in LMICs are likely to have accounted for at least some of the variation found between the current review and that conducted in HICs [59]. Lymphedema incidence and 
Table 3 Risk factors of lymphedema

\begin{tabular}{|c|c|c|c|}
\hline Risk factor & Author & Risk ratio/Hazard ratio & Stage and Measurement \\
\hline \multicolumn{4}{|l|}{ 1. Arm Lymphedema } \\
\hline $\begin{array}{l}\text { BMI > } 25 \\
\text { Age }>60 \\
\text { Number of metastatic LNs } \\
\text { Having a Breast/Chest-wall RT } \\
\text { Having Axillary RT } \\
\text { Lumpectomy }\end{array}$ & (KiBar, Aras et al. 2015) [27] & $\begin{array}{l}5.911 \text { (OR1.698-20.583) } \\
3.680 \text { (OR1.076-12.583) } \\
1.115(\text { OR1.043-1.192) } \\
3.249 \text { (OR1.742-6.060) } \\
4.375(\text { OR1.439-13.306) } \\
0.294(\text { OR0.062-1.402) }\end{array}$ & $\begin{array}{l}\text { Patients undergoing Level III Mastectomy/ } \\
\text { Lumpectomy/ Chemotherapy/ Radiotherapy } \\
\text { Arm circumference measurement }\end{array}$ \\
\hline $\begin{array}{l}\text { Having mastectomy (ALND) + } \\
\text { RT }\end{array}$ & (Ozcinar, Guler et al. 2012) [29] & $\begin{array}{l}\text { Patients with ALND + RT had statistically } \\
\text { increased rate } \\
\text { of lymphedema than patients with ALND } \\
\text { and without RT } \\
(p=0.030)\end{array}$ & $\begin{array}{l}\text { Stage I, II who underwent mastectomy } \\
\text { Arm circumference measurement }\end{array}$ \\
\hline $\begin{array}{l}\text { BMI > } 25 \\
\text { Axillary Radiotherapy } \\
\text { Stage of the cancer (I-III) }\end{array}$ & (Ozaslan and Kuru 2004) [30] & $\begin{array}{l}5.55 \text { (RR2.28-13.51) } \\
\text { 2.75 (RR1.48-5.08) } \\
\text { Not significant }\end{array}$ & $\begin{array}{l}\text { Stage I-III } \\
\text { Arm circumference measurement }\end{array}$ \\
\hline $\begin{array}{l}\text { Number of lymph node } \\
\text { removed } \\
16-25 \\
\text { Removal > } 25 \\
\text { Adjuvant RT + LND } \\
\text { Chemotherapy }\end{array}$ & (Rebegea, Firescu et al. 2015) [21] & $\begin{array}{l}1.85 \text { (OR1.27-2.71) } \\
4.88 \text { (OR2.25-10.58) } \\
3.87 \text { (OR1.39-6.51) } \\
1.45 \text { (OR1.12-2.24) }\end{array}$ & $\begin{array}{l}\text { Stages I-IV } \\
\text { Arm circumference measurement }\end{array}$ \\
\hline $\begin{array}{l}\text { Presence of seroma after breast } \\
\text { cancer surgery } \\
\text { Staging of cancer } \\
\text { Time after surgery }\end{array}$ & (Paiva, Rodrigues et al. 2013) [34] & $\begin{array}{l}2.71(\text { PR1.49-4.91) } \\
1.15(\text { PR0.78-2.92) } \\
\text { Surgery for }>5 \text { years is } 9.7 \text { times higher } \\
\text { frequency than }<5 \text { years }\end{array}$ & $\begin{array}{l}\text { Women undergoing oncology follow up } \\
\text { Perimetry }\end{array}$ \\
\hline $\begin{array}{l}\text { Staging (Locally advanced III) } \\
\text { Post RT skin necrosis }\end{array}$ & (Khanna, Gupta et al. 2019) [41] & $\begin{array}{l}2.21(\mathrm{OR} 0.54-9.04)^{\mathrm{a}} \\
4.34(\mathrm{OR} 1.07-17.65)\end{array}$ & $\begin{array}{l}\text { Early and locally advanced stages } \\
\text { Arm circumference measurement }\end{array}$ \\
\hline $\begin{array}{l}\text { Higher BMI } \\
\text { Increasing number of lymph } \\
\text { nodes dissected } \\
\text { Higher nodal ratio } \\
\text { Regional Lymph Node Radiation } \\
\text { (RLNR) }\end{array}$ & (Rastogi, Jain et al. 2018) [42] & $\begin{array}{l}1.191(\mathrm{HR} 0.809-1.755) \\
1.445 \text { (HR1.116-1.872) } \\
1.135(\mathrm{HR} 1.037-1.243) \\
1.020(\mathrm{HR} 0.042-24.571)\end{array}$ & $\begin{array}{l}\text { Stage } \| \text { - III } \\
\text { Arm circumference measurement }\end{array}$ \\
\hline $\begin{array}{l}\text { Axillary RT } \\
\text { Presence of co-morbid } \\
\text { condition }\end{array}$ & (Deo, Ray et al. 2004) [45] & $\begin{array}{l}0.0709 \text { (HR2.3222-7.1601) } \\
0.1593 \text { (HR1.1441-2.9369) }\end{array}$ & $\begin{array}{l}\text { Stage I-III } \\
\text { Arm circumference measurement }\end{array}$ \\
\hline $\begin{array}{l}\text { Engaging in moderate to severe } \\
\text { physical activity } \\
\text { BMl of } \geq 25 \\
\text { Invasiveness of the tumor } \\
\text { Modified Radical Mastectomy } \\
\text { Having radiotherapy } \\
\text { Past history of limb damage } \\
\text { Number of lymph nodes } \\
\text { removed }\end{array}$ & (Honarvar, Sayar et al. 2016) [47] & $\begin{array}{l}14.0 \text { (OR2.6-73.3) } \\
4.2 \text { (OR2.0-8.7) } \\
13.7 \text { (OR7.3-25.6) } \\
4.3 \text { (OR2.3-7.9) } \\
3.9 \text { (OR1.8-8.2) } \\
1.7 \text { (OR0.9-3.1) } \\
1.1 \text { (OR1.0-1.1) }\end{array}$ & $\begin{array}{l}\text { Women with breast cancer } \\
\text { Arm circumference measurement }\end{array}$ \\
\hline BMI & (Ay, Kutun et al. 2014) [28] & $\begin{array}{l}\text { BMI of } 25-29.9 \text { was } 1.445 \text { times } \\
\text { more likely to develop lymphoedema than } \\
\text { a patient with a BMl } \\
\text { of }<17.9(p<0.001) \text {, and a patient with a } \\
\text { BMl of } 30-34.9 \text { was } \\
6.643 \text { times more likely to develop it than } \\
\text { a patient with a BMl of } \\
<17.9(p<0.001) \text {. }\end{array}$ & $\begin{array}{l}\text { Stage I \& \| } \\
\text { Arm circumference measurement }\end{array}$ \\
\hline \multicolumn{4}{|l|}{ 2. Leg Lymphedema } \\
\hline $\begin{array}{l}\text { Age } \\
\text { BMl } \\
\text { Staging }^{a}\end{array}$ & $\begin{array}{l}\text { (de Melo Ferreira, de Figueiredo } \\
\text { et al. 2012) [49] }\end{array}$ & $\begin{array}{l}1.09(\text { OR1.00-1.18) } \\
1.34(\text { OR1.01-1.77) } \\
0.33(\text { ORO.02-5.33) }\end{array}$ & $\begin{array}{l}\text { Stage I-IV } \\
\text { Clinical diagnosis }\end{array}$ \\
\hline
\end{tabular}

aNot significant in the final model

$R T$ Radiotherapy, $L N$ Lymph node, $B M I$ Body mass index; Lymph node dissection

prevalence were generally higher in our review compared to the previous review of studies conducted in HICs [6]. However, comparability between these reviews is limited by the heterogeneity among estimates and general low quality of studies in LMICs [6]. However, comparability between these reviews is limited by the 
Table 4 Assessment of the risk of bias of included studies

\begin{tabular}{|c|c|c|c|c|c|c|c|c|c|c|}
\hline $\begin{array}{l}\text { Included } \\
\text { study }\end{array}$ & $\begin{array}{l}\text { Appropriate } \\
\text { sampling } \\
\text { frame }\end{array}$ & $\begin{array}{l}\text { Using a } \\
\text { proper } \\
\text { Sampling } \\
\text { technique }\end{array}$ & $\begin{array}{l}\text { Adequate } \\
\text { sample } \\
\text { size }\end{array}$ & $\begin{array}{l}\text { Adequate } \\
\text { description of } \\
\text { study subject } \\
\text { and setting }\end{array}$ & $\begin{array}{l}\text { Sufficient } \\
\text { data } \\
\text { analysis }\end{array}$ & $\begin{array}{l}\text { Use of valid } \\
\text { methods } \\
\text { for the } \\
\text { conditions }\end{array}$ & $\begin{array}{l}\text { Valid } \\
\text { measurement } \\
\text { for all } \\
\text { participants }\end{array}$ & $\begin{array}{l}\text { Using } \\
\text { appropriate } \\
\text { statistical } \\
\text { analysis }\end{array}$ & $\begin{array}{l}\text { Adequate } \\
\text { response } \\
\text { rate }\end{array}$ & $\begin{array}{l}\text { Overall } \\
\text { quality } \\
\text { (Rate } \\
\text { over 9) }\end{array}$ \\
\hline $\begin{array}{l}\text { (Yılmaz and } \\
\text { Coşkun 2019) } \\
\text { [23] }\end{array}$ & 1 & 0 & 0 & 0 & 1 & 1 & 1 & 0 & 0 & $4 / 9$ \\
\hline $\begin{array}{l}\text { (Kibar, Dalyan } \\
\text { Aras et al. } \\
\text { 2017) [25] }\end{array}$ & 1 & 0 & 0 & 0 & 1 & 1 & 1 & 1 & 1 & $6 / 9$ \\
\hline $\begin{array}{l}\text { (Erdogan } \\
\text { lyigun, } \\
\text { Selamoglu } \\
\text { et al. 2015) } \\
\text { [26] }\end{array}$ & 1 & 1 & 0 & 0 & 0 & 1 & 1 & 0 & 1 & $5 / 9$ \\
\hline $\begin{array}{l}\text { (KiBar, Aras } \\
\text { et al. 2015) } \\
\text { [27] }\end{array}$ & 1 & 0 & 0 & 0 & 1 & 1 & 1 & 0 & 1 & $5 / 9$ \\
\hline $\begin{array}{l}\text { (Ay, Kutun } \\
\text { et al. 2014) } \\
{[28]}\end{array}$ & 0 & 1 & 1 & 1 & 1 & 1 & 1 & 0 & 1 & $7 / 9$ \\
\hline $\begin{array}{l}\text { (Ozcinar, Guler } \\
\text { et al. 2012) } \\
\text { [29] }\end{array}$ & 1 & 1 & 0 & 0 & 1 & 1 & 1 & 1 & 0 & $6 / 9$ \\
\hline $\begin{array}{l}\text { (Ozaslan and } \\
\text { Kuru 2004) } \\
\text { [30] }\end{array}$ & 1 & 1 & 0 & 0 & 1 & 1 & 1 & 1 & 1 & $7 / 9$ \\
\hline $\begin{array}{l}\text { (Rebegea, } \\
\text { Firescu et al. } \\
\text { 2015) [21] }\end{array}$ & 1 & 1 & 0 & 0 & 1 & 1 & 1 & 1 & 1 & $7 / 9$ \\
\hline $\begin{array}{l}\text { (Borman, } \\
\text { Yaman et al. } \\
\text { 2018) [31] }\end{array}$ & 1 & 0 & 0 & 0 & 0 & 1 & 1 & 1 & 0 & $4 / 9$ \\
\hline $\begin{array}{l}\text { (Vieira, Silva } \\
\text { et al. 2018) } \\
\text { [32] }\end{array}$ & 1 & 0 & 0 & 0 & 0 & 1 & 1 & 0 & 0 & $3 / 9$ \\
\hline $\begin{array}{l}\text { (Borman, } \\
\text { Yaman et al. } \\
\text { 2017) [51] }\end{array}$ & 1 & 1 & 0 & 0 & 1 & 1 & 1 & 0 & 0 & $5 / 9$ \\
\hline $\begin{array}{l}\text { (Godoy, Dias } \\
\text { et al. 2014) } \\
\text { [33] }\end{array}$ & 0 & 1 & 1 & 0 & 0 & 0 & 1 & 0 & 1 & $4 / 9$ \\
\hline $\begin{array}{l}\text { (Paiva, } \\
\text { Rodrigues } \\
\text { et al. 2013) } \\
\text { [34] }\end{array}$ & 1 & 1 & 0 & 0 & 1 & 1 & 1 & 1 & 1 & $7 / 9$ \\
\hline $\begin{array}{l}\text { (do } \\
\text { Nascimento, } \\
\text { de Oliveira } \\
\text { et al. 2012) } \\
\text { [24] }\end{array}$ & 0 & 1 & 1 & 0 & 0 & 0 & 1 & 0 & 1 & $4 / 9$ \\
\hline $\begin{array}{l}\text { (de Godoy, } \\
\text { Barufi et al. } \\
\text { 2012) [35] }\end{array}$ & 0 & 0 & 0 & 0 & 0 & 1 & 1 & 0 & 0 & $2 / 9$ \\
\hline $\begin{array}{l}\text { (Campanholi, } \\
\text { Duprat et al. } \\
\text { 2011) [20] }\end{array}$ & 0 & 0 & 0 & 0 & 0 & 1 & 1 & 0 & 1 & $3 / 9$ \\
\hline $\begin{array}{l}\text { (Bergmann, } \\
\text { Bourrus et al. } \\
\text { 2011) [36] }\end{array}$ & 1 & 1 & 0 & 0 & 1 & 1 & 1 & 1 & 1 & $7 / 9$ \\
\hline
\end{tabular}


Table 4 Assessment of the risk of bias of included studies (Continued)

\begin{tabular}{|c|c|c|c|c|c|c|c|c|c|c|}
\hline $\begin{array}{l}\text { Included } \\
\text { study }\end{array}$ & $\begin{array}{l}\text { Appropriate } \\
\text { sampling } \\
\text { frame }\end{array}$ & $\begin{array}{l}\text { Using a } \\
\text { proper } \\
\text { Sampling } \\
\text { technique }\end{array}$ & $\begin{array}{l}\text { Adequate } \\
\text { sample } \\
\text { size }\end{array}$ & $\begin{array}{l}\text { Adequate } \\
\text { description of } \\
\text { study subject } \\
\text { and setting }\end{array}$ & $\begin{array}{l}\text { Sufficient } \\
\text { data } \\
\text { analysis }\end{array}$ & $\begin{array}{l}\text { Use of valid } \\
\text { methods } \\
\text { for the } \\
\text { conditions }\end{array}$ & $\begin{array}{l}\text { Valid } \\
\text { measurement } \\
\text { for all } \\
\text { participants }\end{array}$ & $\begin{array}{l}\text { Using } \\
\text { appropriate } \\
\text { statistical } \\
\text { analysis }\end{array}$ & $\begin{array}{l}\text { Adequate } \\
\text { response } \\
\text { rate }\end{array}$ & $\begin{array}{l}\text { Overall } \\
\text { quality } \\
\text { (Rate } \\
\text { over 9) }\end{array}$ \\
\hline $\begin{array}{l}\text { (Velloso, Barra } \\
\text { et al. 2011) } \\
\text { [37] }\end{array}$ & 1 & 0 & 0 & 0 & 1 & 1 & 1 & 0 & 0 & $4 / 9$ \\
\hline $\begin{array}{l}\text { (Alem and } \\
\text { Gurgel 2008) } \\
\text { [38] }\end{array}$ & 1 & 0 & 0 & 1 & 0 & 1 & 1 & 0 & 0 & $4 / 9$ \\
\hline $\begin{array}{l}\text { (Paim, Lima } \\
\text { et al. 2008) [5] }\end{array}$ & 0 & 1 & 1 & 0 & 1 & 1 & 1 & 0 & 1 & $6 / 9$ \\
\hline $\begin{array}{l}\text { (Batiston and } \\
\text { Santiago } \\
\text { 2005) [39] }\end{array}$ & 0 & 0 & 0 & 0 & 1 & 0 & 1 & 1 & 0 & $3 / 9$ \\
\hline $\begin{array}{l}\text { (Elumelu- } \\
\text { Kupoluyi, } \\
\text { Adenipekun } \\
\text { et al. 2013) } \\
\text { [40] }\end{array}$ & 0 & 1 & 0 & 0 & 0 & 1 & 1 & 0 & 0 & $3 / 9$ \\
\hline $\begin{array}{l}\text { (Khanna, } \\
\text { Gupta et al. } \\
\text { 2019) [41] }\end{array}$ & 1 & 1 & 0 & 0 & 0 & 1 & 1 & 1 & 1 & $6 / 9$ \\
\hline $\begin{array}{l}\text { (Rastogi, Jain } \\
\text { et al. 2018) } \\
\text { [42] }\end{array}$ & 1 & 1 & 0 & 0 & 1 & 1 & 1 & 0 & 1 & $6 / 9$ \\
\hline $\begin{array}{l}\text { (Gopal, } \\
\text { Acharya et al. } \\
\text { 2017) [43] }\end{array}$ & 0 & 1 & 0 & 0 & 0 & 1 & 1 & 0 & 1 & $4 / 9$ \\
\hline $\begin{array}{l}\text { (Nandi, } \\
\text { Mahata et al. } \\
\text { 2014) [52] }\end{array}$ & 1 & 0 & 0 & 0 & 0 & 1 & 0 & 0 & 1 & $3 / 9$ \\
\hline $\begin{array}{l}\text { (Raja, Damke } \\
\text { et al. 2014) } \\
\text { [44] }\end{array}$ & 0 & 0 & 0 & 0 & 0 & 0 & 0 & 0 & 1 & $1 / 9$ \\
\hline $\begin{array}{l}\text { (Deo, Ray } \\
\text { et al. 2004) } \\
\text { [45] }\end{array}$ & 1 & 1 & 0 & 0 & 1 & 1 & 1 & 0 & 1 & $6 / 9$ \\
\hline $\begin{array}{l}\text { (Halder, } \\
\text { Morewya et al. } \\
\text { 2001) [46] }\end{array}$ & 0 & 1 & 1 & 1 & 0 & 0 & 0 & 0 & 1 & $4 / 9$ \\
\hline $\begin{array}{l}\text { (Haddad, } \\
\text { Farzin et al. } \\
\text { 2010) [54] }\end{array}$ & 1 & 1 & 1 & 1 & 1 & 1 & 1 & 1 & 1 & $9 / 9$ \\
\hline $\begin{array}{l}\text { (Honarvar, } \\
\text { Sayar et al. } \\
\text { 2016) [47] }\end{array}$ & 1 & 1 & 1 & 0 & 1 & 1 & 1 & 1 & 1 & $8 / 9$ \\
\hline $\begin{array}{l}\text { (Morcos, Al } \\
\text { Ahmad et al. } \\
\text { 2013) [48] }\end{array}$ & 1 & 0 & 1 & 0 & 1 & 1 & 1 & 0 & 1 & $6 / 9$ \\
\hline $\begin{array}{l}\text { (de Melo } \\
\text { Ferreira, de } \\
\text { Figueiredo } \\
\text { et al. 2012) } \\
\text { [49] }\end{array}$ & 1 & 0 & 0 & 0 & 1 & 1 & 0 & 1 & 1 & $5 / 9$ \\
\hline $\begin{array}{l}\text { (Eke, Alabi- } \\
\text { Isama et al. } \\
\text { 2010) [53] }\end{array}$ & 0 & 0 & 0 & 1 & 0 & 0 & 0 & 0 & 1 & $2 / 9$ \\
\hline $\begin{array}{l}\text { (Marin, Pleşca } \\
\text { et al. 2014) }\end{array}$ & 0 & 1 & 1 & 0 & 0 & 0 & 0 & 0 & 1 & $3 / 9$ \\
\hline
\end{tabular}


Table 4 Assessment of the risk of bias of included studies (Continued)

\begin{tabular}{|c|c|c|c|c|c|c|c|c|c|c|}
\hline $\begin{array}{l}\text { Included } \\
\text { study }\end{array}$ & $\begin{array}{l}\text { Appropriate } \\
\text { sampling } \\
\text { frame }\end{array}$ & $\begin{array}{l}\text { Using a } \\
\text { proper } \\
\text { Sampling } \\
\text { technique }\end{array}$ & $\begin{array}{l}\text { Adequate } \\
\text { sample } \\
\text { size }\end{array}$ & $\begin{array}{l}\text { Adequate } \\
\text { description of } \\
\text { study subject } \\
\text { and setting }\end{array}$ & $\begin{array}{l}\text { Sufficient } \\
\text { data } \\
\text { analysis }\end{array}$ & $\begin{array}{l}\text { Use of valid } \\
\text { methods } \\
\text { for the } \\
\text { conditions }\end{array}$ & $\begin{array}{l}\text { Valid } \\
\text { measurement } \\
\text { for all } \\
\text { participants }\end{array}$ & $\begin{array}{l}\text { Using } \\
\text { appropriate } \\
\text { statistical } \\
\text { analysis }\end{array}$ & $\begin{array}{l}\text { Adequate } \\
\text { response } \\
\text { rate }\end{array}$ & $\begin{array}{l}\text { Overall } \\
\text { quality } \\
\text { (Rate } \\
\text { over 9) }\end{array}$ \\
\hline \multicolumn{11}{|l|}{ [50] } \\
\hline $\begin{array}{l}\text { (Dem, Kasse } \\
\text { et al. 2001) } \\
\text { [22] }\end{array}$ & 0 & 1 & 0 & 0 & 0 & 0 & 0 & 0 & 1 & $3 / 9$ \\
\hline
\end{tabular}

heterogeneity among estimates and general low quality of studies in LMICs..

While several different methods are available for measuring lymphedema, the majority of studies included in this review used the circumferential measurements and patients' self-reports. Circumferential measurement is a non-invasive, inexpensive and practical method of lymphedema measurement in the clinical setting $[6,60]$ with established reliability [61]. Self-report, on the other hand, is open to subjective variability between patients and is typically used in the clinic to assess the patient's view of improvement $[6,60]$ and likely to report higher rates compared with the more objective lymphedema measurement methods like circumferential measurements [62]. One study [26] reported on the use of bioimpedance spectroscopy in diagnosing lymphedema. Although this method has demonstrated high sensitivity and specificity, the equipment is expensive and few health facilities even in HICs are able to afford it [63], prohibiting its use in LMICs.

\section{Limitations}

The limitations of this study arise from the limited number of available studies and incomplete reporting, especially with regard to disease stage and treatment. Studies were limited to a small range of countries in certain geographical regions. None of the studies controlled for premorbid lymphedema.

\section{Implications for future research}

Notable gaps that should be filled by future research include studies of the prevalence of lymphedema in certain geographical regions, such as Africa. Because affected people may sometimes resort to traditional and other alternative treatment rather than hospitals in the first instance [64], community-based research may be necessary. In the absence of a gold standard lymphoedema measurement, reaching global consensus on the most reliable and feasible method of identifying lymphedema in LMICs would do much to enable comparability between studies, and to assess the impact of any treatments. Understanding the impact the role of social-determinates of health and culture have on lymphedema prevalence and incidence rates in LMICs are important areas for future research.

Lymph node sparring is considered an invaluable surgical method for lymphedema prevention [65]. However, due to the quality of reporting we were unable to examine its impact on lymphedema prevalence or incidence in LMICs.

\section{Conclusion}

This systematic review and meta-analysis was unable to reliably estimate the prevalence or incidence of lymphedema in LMICs due to heterogeneity (arm lymphedema) and small numbers of studies (leg lymphedema). Heterogeneity among estimates is likely due to differences in measurement methods, as well as variability in stage of cancer, treatments and other variables not reliably reported. Rates were higher according to self-report or compared with more objective measures, such as the clinical diagnosis or the circumferential measurements. Gaining consensus on how best to measure lymphedema in LMICs would enable comparability between studies and more reliable estimates. Better understanding the factors contributing to the wide variability in arm lymphedema is an important first step to developing targeted interventions to improve the quality of life of people living with cancer related lymphedema in LMICs.

\section{Abbreviations \\ LMIC: Low and middle-income countries; EMBASE: Excerpta medica database; CINAHL: Cumulative Index of Nursing and Allied Health Literature; $\mathrm{Cl}$ : Confidence interval; PROSPERO: Prospective Register of Systematic Reviews; PRISMA: Preferred reporting items for systematic reviews and meta- analyses; BMI: Body mass index; HIC: High-income countries; UK: United Kingdom; OR: Odds ratio; HR: Hazard ratio}

\footnotetext{
Acknowledgements

The authors acknowledge the staff and students of IMPACCT, University of Technology Sydney for their immense support during Journal Club Meetings.

\section{Authors' contributions}

All authors developed the protocol, and contributed to the study design, manuscript development, editing, and completion of the manuscript. The article search and management were performed by EL. Article screening was completed by EL, and TL, MAB, and JLP independently screened $10 \%$ of the articles. Quality assessment and study description were performed by EL and $\mathrm{TL}$. The data analysis was done by SC and consensus discussions and finalising with $E L, J P, T L$, and MAB. Table design was completed by $E L, J P$, $M A B, S C$ and $T L$. The authors read and approved the final manuscript.
} 


\section{Funding}

None.

\section{Availability of data and materials}

The datasets used and/or analysed during the current study are available from the corresponding author on reasonable request.

\section{Ethics approval and consent to participate}

This article is based on a secondary analysis of the existing literature and does not contain any studies with human participants or animals performed by any of the authors. The PRISMA guideline for conducting systematic and meta-analysis was followed.

\section{Consent for publication}

Not applicable.

\section{Competing interests}

The authors declare that they have no competing interest.

\begin{abstract}
Author details
${ }^{1}$ Improving Palliative, Aged and Chronic Care through Clinical Research and Translation (IMPACCT), Faculty of Health, University of Technology Sydney, Sydney, New South Wales, Australia. ${ }^{2}$ Department of Physiotherapy and Rehabilitation Sciences, University of Health and Allied Sciences, Ho, Ghana. ${ }^{3}$ Catholic Diocese of Parramatta, Parramatta, New South Wales, Australia.
\end{abstract}

\section{Received: 31 March 2020 Accepted: 15 June 2020}

Published online: 29 June 2020

\section{References}

1. Moseley AL, Carati CJ, Piller NB. A systematic review of common conservative therapies for arm lymphoedema secondary to breast cancer treatment. Ann Oncol. 2006;18(4):639-46.

2. Sekyere MO. Incidence and risk factors of arm lymphedema following breast cancer treatment. American Society of Clinical Oncology; 2018.

3. Paskett ED, Dean JA, Oliveri JM, Harrop JP. Cancer-related lymphedema risk factors, diagnosis, treatment, and impact: a review. J Clin Oncol. 2012;30(30): 3726-33.

4. Grada AA, Phillips TJ. Lymphedema: pathophysiology and clinical manifestations. J Am Acad Dermatol. 2017;77(6):1009-20.

5. Paim CR, Lima EDR, Fu MR, Lima AP, Cassali GD. Postlymphadenectomy complications and quality of life among breast cancer patients in Brazil. Cancer Nurs. 2008;31(4):302-11

6. DiSipio T, Rye S, Newman B, Hayes S. Incidence of unilateral arm lymphoedema after breast cancer: a systematic review and meta-analysis. Lancet Oncol. 2013:14(6):500-15.

7. Cooper G, Bagnall A. Prevalence of lymphoedema in the UK: focus on the southwest and west midlands. Br J Community Nurs. 2016;21(Sup4):S6-S14.

8. Gebruers N, Verbelen H, De Vrieze T, Coeck D, Tjalma W. Incidence and time path of lymphedema in sentinel node negative breast cancer patients: a systematic review. Arch Phys Med Rehabil. 2015;96(6):1131-9.

9. Torgbenu E, Luckett T, Buhagiar MA, Phillips J. Prevalence and incidence of secondary lymphedema in low and middle income countries: a systematic review and meta-analysis; 2019. Available from: https://www.crd.york.ac.uk/ prospero/display_record.php? ID=CRD42019137641.

10. Liberati A, Altman DG, Tetzlaff J, Mulrow C, Gøtzsche PC, loannidis JPA, et al. The PRISMA statement for reporting systematic reviews and meta-analyses of studies that evaluate health care interventions: explanation and elaboration. PLoS Med. 2009:6(7):e1000100.

11. The World Bank Group. World Bank country and lending groups; 2019. Available from: https://datahelpdesk.worldbank.org/knowledgebase/articles/ 906519-world-bank-country-and-lending-groups.

12. Munn Z, Moola S, Lisy K, Riitano D, Tufanaru C. Methodological guidance for systematic reviews of observational epidemiological studies reporting prevalence and cumulative incidence data. Int J Evid-Based Healthc. 2015; 13(3):147-53.

13. Higgins JPT, Green S. Cochrane handbook for systematic reviews of interventions: john Wiley \& sons; 2011.

14. Ressing M, Blettner M, Klug SJ. Data analysis of epidemiological studies: part 11 of a series on evaluation of scientific publications. Deutsches Arzteblatt Int. 2010;107(11):187.
15. Munn Z, Moola S, Riitano D, Lisy K. The development of a critical appraisal tool for use in systematic reviews addressing questions of prevalence. Int J Health Policy Manag. 2014;3(3):123.

16. Bulley C, Gaal S, Coutts F, Blyth C, Jack W, Chetty U, et al. Comparison of breast cancer-related lymphedema (upper limb swelling) prevalence estimated using objective and subjective criteria and relationship with quality of life. Biomed Res Int. 2013;2013.

17. Czerniec SA, Ward LC, Refshauge KM, Beith J, Lee MJ, York S, et al. Assessment of breast cancer-related arm lymphedema-comparison of physical measurement methods and self-report. Cancer Investig. 2010;28(1): 54-62.

18. Langbecker D, Hayes SC, Newman B, Janda M. Treatment for upper-limb and lower-limb lymphedema by professionals specializing in lymphedema care. Eur J Cancer Care. 2008;17(6):557-64.

19. Popay J, Roberts H, Sowden A, Petticrew M, Arai L, Rodgers M, et al. Guidance on the conduct of narrative synthesis in systematic reviews. Prod ESRC Methods Programme Version. 2006;1:b92.

20. Campanholi LL, Duprat JP, Fregnani JHTG. Incidence of LE due to treating cutaneous melanoma. J Lymphoedema. 2011;6(1):30-4.

21. Rebegea $L$, Firescu D, Dumitru M, Anghel R. The incidence and risk factors for occurrence of arm lymphedema after treatment of breast cancer. Chirurgia (Bucharest, Romania: 1990). 2015;110(1):33-7.

22. Dem A, Kasse AA, Diop M, Fall-Gaye MC, Diop PS, Dotou C, et al. Complications of colpohysterectomy with lymph node dissection in the cervix carcinoma at the cancer Institute of Dakar: report of 412 cases. Dakar Med. 2001:46(1):39-42.

23. Yılmaz E, Coşkun T. Meme Kanserli Hastalarda Üst Ekstremite Sorunları ve Yaşam Kalitesi. Med J Bakirkoy. 2019;15(1):29-37.

24. do Nascimento SL, de Oliveira RR, de Oliveira MMF, do Amaral MTP. Complications and physical therapeutic treatment after breast cancer surgery: a retrospective study. Fisioterapia e Pesquisa. 2012;19(3):248-55.

25. Kibar S, Dalyan Aras M, Ünsal DS. The risk factors and prevalence of upper extremity impairments and an analysis of effects of lymphoedema and other impairments on the quality of life of breast cancer patients. Eur 」 Cancer Care. 2017;26(4):1.

26. Erdogan Iyigun Z, Selamoglu D, Alco G, Pilanci KN, Ordu C, Agacayak F, et al. Bioelectrical impedance for detecting and monitoring lymphedema in patients with breast cancer. Preliminary results of the Florence nightingale breast study group. Lymphat Res Biol. 2015;13(1):40-5.

27. Kibar S, Aras MD, SÜ DIAl, BF KS. A cross-sectional study examining the risk factors associated with lymphedema and its prevalence in breast cancer patients after level 3 axillary lymph node dissection. Turkish J Phys Med Rehab. 2015:61(1):36-44.

28. Ay AA, Kutun S, Cetin A. Lymphoedema after mastectomy for breast cancer: importance of supportive care. South Afr J Surg Suid-Afrikaanse Tydskrif vir Chirurgie. 2014;52(2):41-4.

29. Ozcinar B, Guler SA, Kocaman N, Ozkan M, Gulluoglu BM, Ozmen V. Breast cancer related lymphedema in patients with different loco-regional treatments. Breast (Edinburgh, Scotland). 2012;21(3):361-5.

30. Ozaslan C, Kuru B. Lymphedema after treatment of breast cancer. Am J Surg. 2004;187(1):69-72.

31. Borman P, Yaman A, Denizli M, Karahan S, Özdemir O. The reliability and validity of lymphedema quality of life questionnaire-arm in Turkish patients with upper limb lymphedema related with breast cancer. Turkish J Phys Med Rehab (2587-0823). 2018;64(3):205-12.

32. Vieira RA, Silva FC, Silva ME, Silva JJ, Sarri AJ, Paiva CE. Translation and cultural adaptation of the Breast Cancer Treatment Outcome Scale (BCTOS) into Brazilian Portuguese. Revista da Associação Méd Brasileira. 2018;64(7): 627-34.

33. Godoy JMPD, Dias MD, Zaccaro LB, Melina F, Godoy MDFG. Lymphedema post-breast cancer surgery: a populational study. J Phlebology and Lymphol. 2014;7(1):6-8.

34. Paiva DMF, Rodrigues VO, Cesca MG, Palma PV, Leite ICG. Prevalence of lymphedema in women undergoing treatment for breast cancer in a referral center in southeastern Brazil. BMC Womens Health. 2013;13:6.

35. de Godoy JMP, Barufi S, Godoy MFG. Chest lymphedema after breast cancer treatment. J Phlebology Lymphol. 2012;5(1):22-3.

36. Bergmann A, Bourrus NS, de Carvalho CM, de Almeida DR, Fabro EAN, Sales NS, et al. Arm symptoms and overall survival in Brazilian patients with advanced breast cancer. Asian Pac J Cancer Prev. 2011:12(11): 2939-42. 
37. Velloso FSB, Barra AA, Dias RC. Functional performance of upper limb and quality of life after sentinel lymph node biopsy of breast cancer. Brazilian J Phys Ther. 2011;15(2):146-53.

38. Alem M, Gurgel MSC. Acupuncture in the rehabilitation of women after breast cancer surgery -- a case series. Acupunct Med. 2008;26(2):86-93.

39. Batiston AP, Santiago SM. Physical therapy and physical-functional complications after breast cancer surgical treatment. Fisioterapia e Pesquisa. 2005;12(3):30-4

40. Elumelu-Kupoluyi TN, Adenipekun AA, Ntekim Al. Pain associated with secondary lymphedema among cancer patients. J Palliat Care. 2013;29(4):253-7.

41. Khanna S, Gupta AK, Cherian AJ, Yadav B, Jacob PM. Post mastectomy lymphedema-a prospective study of incidence and risk factors. Indian J Surg. 2019;81(1):16-22

42. Rastogi K, Jain S, Bhatnagar A-R, Gupta S, Bhaskar S, Spartacus RK. Breast cancer-related lymphedema in postmastectomy patients receiving adjuvant irradiation: a prospective study. Indian J Cancer. 2018;55(2):184-9.

43. Gopal V, Acharya A, Narayanaswamy V, Pal S. A cross-sectional study on the prevalence and risk factors of lymphedema in carcinoma breast. Asian J Pharm Clin Res. 2017:10(6):240-2.

44. Raja KD, Damke US, Bhave S, Kulsange MM. A study of common Impairements following modified radical mastectomy. Indian J Physiother Occup Ther. 2014;8(4):117-22.

45. Deo SV, Ray S, Rath GK, Shukla NK, Kar M, Asthana S, et al. Prevalence and risk factors for development of lymphedema following breast cancer treatment. Indian J Cancer. 2004;41(1):8.

46. Halder A, Morewya J, Watters DA. Rising incidence of breast cancer in Papua New Guinea. ANZ J Surg. 2001;71(10):590-3.

47. Honarvar B, Sayar N, Tahmasebi S, Zakeri Z, Talei A, Rostami S, et al. Correlates of lymphedema in women with breast cancer: a case control study in shiraz, southern Iran. Asian Pac J Cancer Prev. 2016;17(S3):81-6.

48. Morcos BB, Al Ahmad F, Anabtawi I, Abu Sba A-M, Shabani H, Yaseen R. Lymphedema. A significant health problem for women with breast cancer in Jordan. Saudi Med J. 2013;34(1):62-6.

49. de Melo Ferreira AP, de Figueiredo EM, Lima RA, Candido EB, de Castro Monteiro MV, de Figueiredo Franco TMR, et al. Quality of life in women with vulvar cancer submitted to surgical treatment: a comparative study. Eur J Obstet Gynecol Reprod Biol. 2012;165(1):91-5.

50. Marin F, Pleşca M, Bordea Cl, Voinea SC, Burlănescu I, Ichim E, et al. Postoperative surgical complications of lymphadenohysterocolpectomy. J Med Life. 2014;7(1):60-6.

51. Borman P, Yaman A, Yasrebi S, Özdemir O, Borman P, Yaman A, et al. The importance of awareness and education in patients with breast cancerrelated lymphedema. J Cancer Educ. 2017;32(3):629-33.

52. Nandi M, Mahata A, Mallick I, Achari R, Chatterjee S. Hypofractionated radiotherapy for breast cancers--preliminary results from a tertiary care center in eastern India. Asian Pac J Cancer Prev. 2014;15(6):2505-10.

53. Eke AC, Alabi-Isama LI, Akabuike JC. Management options for vulvar carcinoma in a low resource setting. World J Surg Oncol. 2010;8:94.

54. Haddad P, Farzin M, Amouzegar-Hashemi F, Kalaghchi B, Babazadeh S, Mirzaei $\mathrm{H}$-R, et al. A multicentre cross-sectional study of arm lymphedema four or more years after breast cancer treatment in Iranian patients. Breast Cancer (Tokyo, Japan). 2010;17(4):281-5.

55. Schaverien MV, Moeller JA, Cleveland SD. Nonoperative treatment of lymphedema 2018: Thieme Medical Publishers; 2018.

56. Invernizzi M, Michelotti A, Noale M, Lopez G, Runza L, Giroda M, et al. Breast cancer systemic treatments and upper limb lymphedema: a risk-assessment platform encompassing tumor-specific pathological features reveals the potential role of Trastuzumab. J Clin Med. 2019;8(2):138.

57. Tsai RJ, Dennis LK, Lynch CF, Snetselaar LG, Zamba GKD, Scott-Conner C. The risk of developing arm lymphedema among breast cancer survivors: a meta-analysis of treatment factors. Ann Surg Oncol. 2009;16(7):1959-72.

58. Wernicke AG, Goodman RL, Turner BC, Komarnicky LT, Curran WJ, Christos PJ, et al. A 10-year follow-up of treatment outcomes in patients with early stage breast cancer and clinically negative axillary nodes treated with tangential breast irradiation following sentinel lymph node dissection or axillary clearance. Breast Cancer Res Treat. 2011;125(3):893-902.

59. Ganz PA, Yip CH, Gralow JR, Distelhorst SR, Albain KS, Andersen BL, et al. Supportive care after curative treatment for breast cancer (survivorship care): resource allocations in low-and middle-income countries. A breast health global initiative 2013 consensus statement. Breast. 2013;22(5):606-15.
60. Hayes SC, Johansson K, Stout NL, Prosnitz R, Armer JM, Gabram S, et al. Upper-body morbidity after breast cancer: incidence and evidence for evaluation, prevention, and management within a prospective surveillance model of care. Cancer. 2012;118(S8):2237-49.

61. Foroughi N, Dylke ES, Paterson RD, Sparrow KA, Fan J, Warwick EBG, et al. Inter-rater reliability of arm circumference measurement. Lymphat Res Biol. 2011;9(2):101-7.

62. Armer JM, Ballman KV, McCall L, Armer NC, Sun Y, Udmuangpia T, et al. Lymphedema symptoms and limb measurement changes in breast cancer survivors treated with neoadjuvant chemotherapy and axillary dissection: results of American College of Surgeons oncology group (ACOSOG) Z1071 (Alliance) substudy. Support Care Cancer. 2019;27(2):495-503.

63. Cheville AL, Nyman JA, Pruthi S, Basford JR. Cost considerations regarding the prospective surveillance model for breast cancer survivors. Cancer. 2012; 118(S8):2325-30.

64. Muhamad M, Merriam S, Suhami N. Why breast cancer patients seek traditional healers. Int J Breast Cancer. 2012;2012:1.

65. Hochhauser D. NEWS sparing the lymph nodes but saving the patient. Lancet. 1996;348(9043):1723.

\section{Publisher's Note}

Springer Nature remains neutral with regard to jurisdictional claims in published maps and institutional affiliations.

\section{Ready to submit your research? Choose BMC and benefit from:}

- fast, convenient online submission

- thorough peer review by experienced researchers in your field

- rapid publication on acceptance

- support for research data, including large and complex data types

- gold Open Access which fosters wider collaboration and increased citations

- maximum visibility for your research: over $100 \mathrm{M}$ website views per year

At $\mathrm{BMC}$, research is always in progress.

Learn more biomedcentral.com/submissions 